\title{
Can artificial diets be a feasible alternative for the gonadal growth and maturation of the sea urchin Paracentrotus lividus (Lamarck, 1816)?
}

\author{
Pedro M. Santos $^{1}$ | Susana M. F. Ferreira ${ }^{1,2}$ | Pedro Albano ${ }^{1}$ | \\ Andreia Raposo $^{1}$ | José L. Costa ${ }^{3}$ | Ana Pombo ${ }^{1}$ (1) \\ ${ }^{1}$ MARE-Marine and Environmental Sciences Centre, ESTM, Polytechnic Institute of Leiria, Peniche, Portugal \\ ${ }^{2}$ CFE-Centre for Functional Ecology, Department of Life Science, University of Coimbra, Coimbra, Portugal \\ ${ }^{3}$ MARE-Marine and Environmental Sciences Centre, Faculdade de Ciências, Universidade de Lisboa, Lisbon, Portugal
}

\section{Correspondence}

Ana Pombo, Polytechnic Institute of Leiria,

Campus 4, Santuário de Nossa Senhora dos Remédios, 2520-641 Peniche, Portugal.

Email: ana.pombo@ipleiria.pt

\section{Funding information}

Fundação para a Ciência e Tecnologia (FCT), Grant/Award Number: UID/

MAR/04292/2019; Operational Programme MAR2020, Grant/Award Number:

16-02-01-FMP-0004

\begin{abstract}
Paracentrotus lividus (Lamarck 1816) has high-value reddishorange gonads that are regarded as a delicacy. In this study, three jellified diets have been tested for 90 days to assess the effect of different diets on P. lividus somatic and gonadal growth, gonad color, and reproductive state. All diets contained agar as a gelling agent and consisted of: maize and spinach (A); maize, spinach, and macroalga Laminaria digitata (B); and maize, spinach, and pumpkin Cucurbita maxima (C). Diet $B$ was the most successful in promoting somatic growth with regard to test diameter (1.2 $\left.\mathrm{mm} \mathrm{month}^{-1}\right)$ and total wet weight $\left(79.9 \mathrm{mg}^{\text {ind }}{ }^{-1} \mathrm{day}^{-1}\right)$. The individuals from Diet $A$ presented a higher final gonadosomatic index (9.07 $\pm 2.39 \%$ ) where all sea urchins initially presented with an index of $3.33 \pm 0.02 \%$. Diets $A$ and $C$ led to a marked advance $(p<.05)$ in the gametogenic cycle $(66.7 \%$ and $46.7 \%$ of the individuals with mature gametes, respectively), while Diet B resulted in less-developed gonadal stages, which are more appropriate for commercial purposes in terms of sensorial characteristics appreciated by the consumers. The gonad color analyses confirmed a redder roe in
\end{abstract}


females and also the suitability of $C$. maxima as a potential gonad color enhancer for $P$. lividus.

\section{KEYWORDS}

gonad maturation, histology, nutrition, reproductive cycle

\section{1 | INTRODUCTION}

Nowadays, sea urchin gonads are highly regarded as a luxury food item. Around 105,000 tons of sea urchins are consumed annually, with an estimated value of 0.3 million euros (FAO, 2018). The most important market for sea urchin gonads is observed to be Japan (Hagen, 1996; Stefánsson, Kristinsson, Ziemer, Hannon, \& James, 2017). In Europe, France represents the main market for sea urchin gonads, although on a smaller scale (Le Gall, 1990). Paracentrotus lividus is the most consumed sea urchin in Europe (Carboni, Vignier, Chiantore, Tocher, \& Migaud, 2012). It is geographically distributed throughout the rocky intertidal and shallow subtidal zones of the Mediterranean Sea, the Adriatic Sea, and on the Northeastern Atlantic coasts, from Western Scotland and South West Ireland to the South of Morocco, including the Canary Islands and the Azores Islands (Boudouresque \& Verlaque, 2007; Domínguez, Godino, Freitas, Machado, \& Bertocci, 2015; Fernandez, 1997; San Martin, 1995). Its reddish-orange gonads are considered a delicacy since ancient Greece. Nowadays, they are marketed fresh, frozen, dried, salted, and pasteurized (Hagen, 1996; Sartori, 2013). P. lividus is a regular sea urchin, presenting five gonads, which include germinal cells (GCs) and somatic cells. These latter cells are also called nutritive phagocytes (NPs) (Ghisaura et al., 2016), which store nutrient and energy reserves for gametogenesis (Ghisaura et al., 2016; Harrington, Walker, \& Lesser, 2007; Walker, Unuma, \& Lesser, 2007). This species represents an important economic resource in France, Spain, Italy (Boudouresque \& Verlaque, 2007; Guidetti, Terlizzi, \& Boero, 2004), and, to a lesser extent, Portugal (Jacinto, Bulleri, Benedetti-Cecchi, \& Cruz, 2013). Therefore, it has been subject to intense harvesting in the last decades, particularly in the Mediterranean Sea (Ceccherelli, Pais, Pinna, Sechi, \& Chessa, 2011; Ceccherelli, Pinna, \& Sechi, 2009), on the Atlantic coasts of France and the Iberian Peninsula (Barnes \& Crook, 2001), and in Ireland (Byrne, 1990), which has led to the collapse of many populations (Barnes \& Crook, 2001; Barnes, Verling, Crook, Davidson, \& O'Mahoney, 2002; Bertocci et al., 2014; C. Pearce, 2010; Sartori, Pellegrini, Macchia, \& Gaion, 2016). The situation is further aggravated by the slow growth rate of $P$. lividus of approximately $1 \mathrm{~cm}$ per year in the first 5 years following benthic recruitment (Boudouresque \& Verlaque, 2007; J. Gago, Range, \& Luís, 2003; Grosjean, Spirlet, \& Jangoux, 2003).

The interest in commercial sea urchin aquaculture, or echinoculture (Hagen, 1996), has increased recently to partially replace the steady decline in natural captures (Grosjean, Spirlet, Gosselin, Vaitilingon, \& Jangoux, 1998) but also to make available adult individuals with excellent quality gonads throughout the year (Carboni, 2013). In 2010, marine aquaculture produced 384,300 tons of echinoderms for consumption worldwide (FAO, 2012), in which sea urchins were produced at an estimated value of 88,000 tons (Carboni, Addis, Cau, \& Atack, 2012). According to FAO (2013), the production of $P$. lividus in aquaculture systems corresponds to 10 tons per year ${ }^{-1}$ in Europe in contrast to a landing activity of 108 tons per year ${ }^{-1}$ (Sartori et al., 2016).

P. lividus is mainly an herbivore, consuming algae and seagrass, when such resources are nonlimited (Neill \& Pastor, 1973; Verlaque, 1987). Laminaria digitata ([Hudson] J. V. Lamouroux, 1813) is one of the most preferred natural foods for $P$. lividus; however, the use of macroalgae in large-scale aquaculture is marked by some disadvantages: fluctuating availability and nutritional value throughout the year, along with the cost of collecting and storing large amounts of macroalgae (Basuyaux \& Blin, 1998; FAO, 2016; C. M. Pearce, Daggett, \& Robinson, 2002; Schiener, Black, Stanley, \& Green, 2015). Therefore, modern aquaculture is turning to alternative products, particularly land vegetable products (Turchini, Torstensen, \& Ng, 2009), which allow the recycling of unprocessed agricultural discards 
into biomass of high commercial value (Vizzini, Miccichè, Vaccaro, \& Mazzola, 2015). Furthermore, it allows replacing fishmeal and oil with land-based vegetables, which is much more feasible for the husbandry of herbivorous species (Hardy \& Tacon, 2002). In this context, several authors have referred to the use of maize (Zea mays Linnaeus, 1753) in artificial diets for sea urchins; in particular, Basuyaux and Blin (1998), Basuyaux and Mathieu (1999), Luís, Delgado, and Gago (2005), J. M. Gago, Luís, and Repolho (2009), J. Gago and Luís (2010), J. Gago, Martins, Luís, and PousãoFerreira (2010), Repolho, Costa, Luís, and Gago (2011), J. Gago and Luís (2011), Sartori (2013), Sartori, Scuderi, Sansone, and Gaion (2015), Tomšić, Conides, and Aničić (2015) and Sartori et al. (2016). Additionally, Sartori (2013), Sartori and Gaion (2015), Sartori et al. (2015), and Sartori et al. (2016) refer to the use of spinach (Spinacia oleracea Linnaeus, 1753) as a promising source of nutrients for P. lividus. However, there is a great need to improve diets in order to maintain or enhance the commercially acceptable color and brightness of the gonads. Usually, artificial diets produce large gonads that are pale in color (Shpigel, McBride, Marciano, Ron, \& Ben-Amotz, 2005). Hence, it is necessary to use ingredients rich in carotenoids to overcome this limitation (Britton, Liaaen-Jensen, \& Pfander, 2004; Lawrence, 2007). In this context, given the high carotenoid content of pumpkins (Kim, Kim, Kim, Choi, \& Lee, 2012), Cucurbita maxima Duchesne represents a promising ingredient in the formulation of artificial diets for $P$. lividus.

For the creation of research-oriented trial diets, which can later lead to extruded or pelleted industrial feeds (Fabbrocini, Volpe, Coccia, D'Adamo, \& Paolucci, 2015), natural polysaccharide agar has been used for the formulation of P. lividus artificial diets (Fabbrocini et al., 2012, 2015; Shpigel, Schlosser, Ben-Amotz, Lawrence, \& Lawrence, 2006; Vergés, Alcoverro, \& Romero, 2011; Vergés, Becerro, Alcoverro, \& Romero, 2007). Agar's binding properties, three-dimensional network, and insolubility in cold water allow the formulation of biocomposites, in which different foods and nutrients can be incorporated (Atef, Rezaei, \& Behrooz, 2014; Volpe, Malinconico, Varricchio, \& Paolucci, 2010).

The effects of the three artificial diets were tested on P. lividus by measuring the somatic growth, gonadosomatic index $(\mathrm{Gl})$, reproductive development, and color characteristics of the gonads in a rearing trial that lasted 90 days.

\section{2 | MATERIALS AND METHODS}

\section{1 | Experimental design}

The three sea urchin culture systems used to test the different diets consisted of three 60-L recirculating tanks with a 70-L sump tank. Each aquaculture recirculating system (RAS) was equipped with a water chiller, mechanical and biological filtration (wool and sponge filters, bio balls), a protein skimmer, and a water recirculation pump. Aeration was supplied to each tank and sump. In order to ensure water quality, temperature, $\mathrm{pH}$, dissolved oxygen, and salinity were measured every day in the three rearing systems with a YSI Professional Plus multiparameter instrument (YSI Inc., Yellow Springs, OH). Water samples were collected every week for the determination of ammonia, nitrate, nitrite, and phosphate concentrations through a photometric method, using a Hanna HI 83203 multiparameter bench photometer for aquaculture (Hanna Instruments Inc., Woonsocket, RI).

\subsection{Sea urchin collection and fasting period}

A total of 153 wild adult $P$. lividus, with a test diameter ranging from 30 to $45 \mathrm{~mm}$, were collected in the intertidal zone of Praia do Abalo in Peniche, Portugal ( $\left.39^{\circ} 22^{\prime} 12.7^{\prime \prime} \mathrm{N}, 9^{\circ} 23^{\prime} 08.2^{\prime \prime} \mathrm{W}\right)$. Sea urchins were then acclimated in the aquaculture laboratory of MARE-Marine and Environmental Sciences Centre (ESTM, Polytechnic Institute of Leiria) for approximately 2 weeks at a temperature of $20 \pm 1^{\circ} \mathrm{C}$ and were fed with macroalgae (Codium tomentosum Stackhouse, 1797 and L. digitata). Thereafter, sea urchins were subjected to a fasting period of 30 days in order to induce reabsorption of the gonads through the consumption of their content, hence resetting the reproductive cycle to the spent stage (Spirlet, Grosjean, \& Jangoux, 1998b). The water parameters were measured daily and were as follows: 
$16.17 \pm 0.68^{\circ} \mathrm{C}$ water temperature, $35.5 \pm 0.33$ salinity, $8.1 \pm 0.05 \mathrm{pH}$, and $93 \pm 1 \%$ dissolved oxygen. At the end of the fasting period, six individuals per system (18 individuals in total) were sampled and weighed (individual total wet weight, $\pm 0.01 \mathrm{~g}$ ), measured with a caliper (test diameter, $\pm 0.1 \mathrm{~mm}$ accuracy), and dissected with the objective of estimating the morphometric and reproductive conditions of the sea urchins before the feeding trial (namely, the GI). Moreover, their gonads were carefully removed, weighed $( \pm 0.01 \mathrm{~g})$, and immediately fixed in a $10 \%$ formalin solution for $24 \mathrm{hr}$.

\section{3 | Feeding trial}

To perform the feeding trial (T1), 45 individuals per system were measured with a caliper (test diameter, $\pm 0.1 \mathrm{~mm}$ accuracy), briefly drip-dried with absorbent paper, and weighed (individual total wet weight, $\pm 0.01 \mathrm{~g}$ ). Subsequently, the feeding experiment with the three jellified diets was conducted over a period of 90 days. The stock density was 0.25 ind $\mathrm{L}^{-1}$ (Fabbrocini et al., 2012). During this period, the values of the water parameters were as follows: 19.09 $\pm 0.91^{\circ} \mathrm{C}$ temperature, $8.0 \pm 0.16 \mathrm{pH}, 94.4 \pm 1.3 \%$ dissolved oxygen, $35.7 \pm 0.82$ salinity, $0.54 \pm 0.3 \mathrm{mg} \mathrm{L}^{-1} \mathrm{ammo}^{-}$ nia, $0.06 \pm 0.04 \mathrm{mg} \mathrm{L}^{-1}$ nitrite, $0.67 \pm 0.59 \mathrm{mg} \mathrm{L}^{-1}$ nitrate, and $0.19 \pm 0.13 \mathrm{mg} \mathrm{L}^{-1}$ phosphate.

\subsection{Diet formulation and feeding routine}

The three diets were formulated with organic fresh spinach, canned maize, L. digitata from the sampling site, C. maxima pumpkin from organic farming, and agar powder as a gelling agent. The diets were prepared as follows: Diet A-47\% maize (Z. mays), 47\% spinach (S. oleracea), and 6\% agar; Diet B-50\% macroalgae (L. digitata), 22\% maize (Z. mays), 22\% spinach (S. oleracea), and 6\% agar; and Diet C-50\% pumpkin (C. maxima), 22\% maize (Z. mays), 22\% spinach (S. oleracea), and 6\% agar.

Diets were cut daily into feed pellets of approximately $3.0 \times 3.0 \times 1.5 \mathrm{~cm}$ (length $\times$ width $\times$ height) and manually administered ad libitum in the evening (Fernandez \& Boudouresque, 2000; Heflin et al., 2016). For each tank, the supplied feed was weighed $( \pm 0.01 \mathrm{~g}$ ), and $9 \mathrm{hr}$ later, the uningested feed was carefully collected, dried on absorbent paper, and weighed to calculate the feed intake (wet weight). With this information, the amount of feed provided to each tank was adapted on a daily basis to consistently obtain a significant portion of waste (at least $20 \%$ of the provided biomass).

\subsection{End of the feeding trial}

After 90 days of rearing $P$. lividus, all individuals $(N=135)$ were measured with a caliper (test diameter, $\pm 0.1 \mathrm{~mm}$ accuracy), briefly drip-dried with absorbent paper and weighed (individual total wet weight, $\pm 0.01 \mathrm{~g}$ ). Then, the sea urchins were dissected, and the gonads were carefully removed and wet-weighed $( \pm 0.0001 \mathrm{~g})$. One of the five gonads was randomly chosen to be immediately photographed, under controlled conditions, for color analysis (Hu, Cline, Davis, Wang, \& Liu, 2015; Li, Ning, \& Jing, 2017; Schur \& Tappert, 2017; Svensson, Pélabon, Blount, Surai, \& Amundsen, 2006; Yam \& Papadakis, 2004). Regarding the histological study of gametogenesis, 10 sea urchins from each tank were randomly selected, and two gonads from each individual were immediately placed in $10 \%$ formalin. With the obtained results, GI, daily growth rate (DGR), total wet weight gain (TWG), and linear growth rate (LGR) were calculated to compare the somatic and gonadal growth of the individuals fed the three diets.

\subsection{Photography and color analysis}

A DSLR Canon EOS 70D (Canon Inc., Tokyo, Japan), coupled with a Tamron SP AF 90 mm F/2.8 Di Macro 1:1 lens (Tamron, Tokyo, Japan), was mounted to a Sachtler Ace M GS tripod (Sachtler GmbH \& Co., Eching, Germany) in a dark room facing a table covered with a black sponge, where the gonads were placed. Two fluorescent lamps (T5, 
$18 \mathrm{~W} / 765$ daylight) were positioned on the two sides of this area, below the camera, with a constant light intensity of 1,435 Ix, measured with a Milwaukee SM700 Luxmeter (Milwaukee Inc., Rocky Mount, NC). The camera control settings were kept constant for all of the 135 photographs and were as follows: manual (exposure mode), Medium Raw format, 800 ISO, 1/125 s (shutter speed), F/4.5 (aperture), 0 EV (exposure compensation), and no flash. The resulting digital images were all 4,104 ×2,736 pixels in the Canon's uncompressed file extension CR2.

To objectively evaluate the color of the gonads, their digital photographs were analyzed with Adobe Photoshop CC 2015 image software (Adobe Systems Inc., San Jose, CA), which allows an advanced and reliable color analysis (Hu et al., 2015; Svensson et al., 2006; Yam \& Papadakis, 2004). The CR2 digital images were converted into the PNG image format because of its versatility and lossless compression scheme (Wiggins, Davidson, Harnsberger, Lauman, \& Goede, 2001). The images were then converted to CIE L*a*b* (also known as CIELAB or CIE76 as it was established by the International Commission on Illumination in 1976), regarded as the most complete and perceptually uniform color space, which is also device-independent (Li et al., 2017; Schur \& Tappert, 2017). As a* represents the balance between green ( $(-)$ and red (+), it was used to define the "redness" of each gonad, which is the most appreciated characteristic by consumers of $P$. lividus. It is also highly related to carotenoid concentration (Hatlen, Jobling, \& Bjerkeng, 1998). For each photograph, the gonad was isolated from the black background with the Photoshop's Quick Selection Tool, and then, the mean value of the a* parameter was registered using the Histogram tool. These procedures allowed the comparison of all individuals from the three diets ( 45 individuals per diet).

\section{7 | Gender ratio and gametogenic stages}

Two intact gonads from each sea urchin were fixed in a 10\% formalin solution (Sartori \& Gaion, 2015) for $48 \mathrm{hr}$. The samples were processed by a Leica ${ }^{\circledR}$ TP1020 Automatic Tissue Processor (Leica Microsystems GmbH, Wetzlar, Germany), with sequential submersions in graded ethanol for dehydration, followed by xylene for clarification and impregnation with paraffin wax at $60^{\circ} \mathrm{C}$. Subsequently, gonad samples were embedded in $100 \%(\mathrm{v} / \mathrm{v})$ paraffin, cut with a thickness of $5 \mu \mathrm{m}$ (Carboni, Hughes, Atack, Tocher, \& Migaud, 2013; Paredes \& Bellas, 2014) using an AccuCut $^{\circledR}$ SRM ${ }^{\mathrm{TM}} 200$ Rotary Microtome (Sakura Finetek Europe BV, Alphen aan den Rijn, The Netherlands) and stained with Harris' hematoxylin solution (Scharlab S.L., Sentmenat, Barcelona, Spain) and eosin Y (yellowish) (VWR International, Leuven, Belgium). Gonad slides were analyzed using a Leica ${ }^{\circledR}$ DM 2000 LED light optical microscope equipped with a Leica ${ }^{\circledR}$ MC170 5MP HD Microscope Camera and the combined LAS V4.4.0 software (Leica Application Suite) for monitor display (Leica Microsystems $\mathrm{GmbH}$ ). The gonads were classified according to Spirlet, Grosjean, and Jangoux (1998a) into eight gametogenic stages: stage I (spent with relict), stage II (spent empty), stage III (recovery), stage IV (growing), stage V (premature), stage VI (mature), stage VII (partly spawned), and stage VIII (posts-pawned). The size frequencies of the oocytes were obtained using the LAS software distance line tool, performed at $\times 20$ magnification. For each female individual, 50 oocytes/ova sectioned through the nucleolus/nucleus were randomly selected to measure the corresponding long diameter to the nearest $0.001 \mu \mathrm{m}$. Relict oocytes were not considered (Bronstein, Kroh, \& Loya, 2016; Byrne, 1990).

\section{8 | Data analyses}

The feed intake per tank was calculated daily as the difference between the given feed and the leftovers. It was presented as $g_{\text {day }^{-1}}$ individual $^{-1}$ (wet weight; mean \pm SD) (Vizzini et al., 2015).

After the fasting period and at the end of the feeding trial, the $\mathrm{Gl}$ of $P$. lividus was calculated according to Sartori and Gaion (2015) and Carboni, Hughes, Atack, Tocher, and Migaud (2015):

$$
\mathrm{GI}=\frac{\text { gonads wet weight }(\mathrm{g})}{\text { total wet weight }(\mathrm{g})} \times 100 \text {. }
$$


The DGR, TWG, and LGR were calculated after the feeding trial to compare the somatic and gonadal growth of the individuals fed the three diets.

DGR (in \% day ${ }^{-1}$ ) was calculated as follows:

$$
D G R=\left[\left(\frac{W_{\text {final }}}{W_{\text {initial }}}\right)^{1 / t}-1\right] \times 100
$$

where $W_{\text {initial }}$ and $W_{\text {final }}$ are the mean initial and final total wet weight $(g)$ of the individuals, respectively, and $t$ is the number of days of the trial (Basuyaux \& Blin, 1998).

TWG of the individuals (TWG in mg ind ${ }^{-1}$ day $^{-1}$ ) was adapted from Shpigel, McBride, Marciano, and Lupatsch (2004) as follows:

$$
\text { Weight gain }=\frac{\left(W_{\text {final }}-W_{\text {initial }}\right)}{t},
$$

where $W_{\text {final }}$ and $W_{\text {initial }}$ represent the final and initial mean total wet weight $(\mathrm{mg})$, respectively, and $t$ represents time in days.

The LGR was adapted from Cook and Kelly (2009) and calculated in mm month ${ }^{-1}$ as follows:

$$
\mathrm{LGR}=\frac{\left(L_{f}-L_{i}\right)}{t}
$$

where $L_{f}$ and $L_{i}$ were the final and initial mean test diameters $(\mathrm{mm})$, respectively, and $t$ represents time in days.

All statistical tests were performed using IBM SPSS ${ }^{\text {тM }}$ Statistics for Windows, version 23 (IBM Corporation, Armonk, NY). Results were expressed as mean \pm SD, and a value of $\alpha=.05$ was chosen as the level for significance. All data were assessed with the Shapiro-Wilk test for normal distribution and with Levene's test for homogeneity of variances to meet the assumptions of the analysis of variance (ANOVA). One-way ANOVAs $\left(F_{\text {[degrees of freedom between groups, degrees of freedom within groups] }}=\right.$ value; $p$-value) were used at the beginning and end of the trial to compare the test diameter and individual total wet weight between individuals fed the different diets, as well as the GI, oocyte diameter, and a* color parameter regarding the different diet groups, at the end of the trial. Two-way ANOVAs were performed to search for differences in test diameter and total wet weight using diet and time period (beginning and end of the feeding trial) as independent variables. Whenever the ANOVA assumptions failed, the nonparametric Kruskal-Wallis test $\left(H_{\text {[degrees of freedom] }}=\right.$ value; $p$-value) was used to compare the total feed intake of the diets by the sea urchins. In case of statistically significant differences, post-hoc multiple pairwise comparisons were performed using the Tukey HSD test or Holm-Sidak's test for parametric data and Mann-Whitney $U$ test with Bonferroni correction for nonparametric data. An independent $t$-test $\left(t_{\text {[degrees of freedom] }}=\right.$ value; $p$-value) was used to compare the $a^{*}$ color parameter of the gonads between males and females. Goodness-of-fit chi-square tests were used to assess differences between the initial and final maturation states of the gonads for the sea urchins from each diet. To search for a possible association between diets and gametogenic stages, a chi-square test of association was used at the end of the feeding trial. The results were presented as $\chi^{2}$ (degrees of freedom) $=$ value; $p$-value.

\section{\begin{tabular}{l|l}
3 & RESULTS
\end{tabular}}

In the fasting period of 30 days, which was performed with 51 sea urchins per system, no mortality occurred. Furthermore, during the feeding trial of 90 days, all 135 individuals survived until the end of the experiment. 


\section{1 | Test diameter}

The initial test diameter (T1; $n=45)$ was as follows for each diet: $35.7 \pm 3.1 \mathrm{~mm}$ (Diet A), $35.0 \pm 3.1 \mathrm{~mm}$ (Diet B), and $35.9 \pm 3.1 \mathrm{~mm}$ (Diet C) as shown in Figure 1. No significant differences in the initial test diameter were found between the groups used for the feeding trial as assessed by one-way ANOVA $\left[F_{(2,132)}=0.927 ; p>.05\right]$. At the end of the trial (T2), significant diameter differences were observed between the three diet groups using a one-way ANOVA $\left[F_{(2,132)}=4.22 ; p<.05\right]$. Post-hoc comparisons indicated that the test diameter of sea urchins from Diet B $(38.6 \pm 2.4 \mathrm{~mm})$ was significantly higher than that of Diet $\mathrm{C}(37.2 \pm 3.1 \mathrm{~mm}, p<.05)$, but there were no significant differences between Diets B and A (37.2 $\pm 2.9 \mathrm{~mm}, p>.05)$, as well as between Diets A and C ( $p>.05)$. Moreover, the diameter was distinct according to the time period considered $\left[F_{(1,264)}=34.209 ; p<.05\right]$ as the sea urchins were significantly larger when compared to the beginning of the trial in Diet A $(p<.05)$, Diet B $(p<.05)$, and Diet C $(p<.05)$, showing a significant interaction time period $\times \operatorname{diet}\left[F_{(2,264)}=4.319 ; p<.05\right]$. Therefore, Diet $B$ was the most successful in promoting growth in terms of the test diameter, with a LGR of $1.2 \mathrm{~mm} \mathrm{month}{ }^{-1}$, followed by Diet A $\left(0.5 \mathrm{~mm} \mathrm{month}^{-1}\right)$ and Diet C (0.4 $\left.\mathrm{mm} \mathrm{month}^{-1}\right)$.

\section{2 | Total wet weight}

The initial individual total wet weight $(\mathrm{T} 1 ; n=45)$ was as follows for each diet: $22.46 \pm 4.99 \mathrm{~g}$ (Diet $\mathrm{A}), 23.00$ $\pm 5.23 \mathrm{~g}$ (Diet B), and $21.48 \pm 4.99 \mathrm{~g}$ (Diet C), as shown in Figure 2, without significant differences found between groups $\left[F_{(2,150)}=1.223 ; p>.05\right]$. After the feeding trial $(T 2)$, significant total wet weight differences were found between the sea urchins from the three diet groups using a one-way ANOVA $\left[F_{(2,132)}=9.058 ; p<.05\right]$. Post-hoc comparisons indicated that the total wet weight of the individuals from Diet B (30.19 $\pm 5.18 \mathrm{~g})$ was significantly higher than those from Diet $A(26.10 \pm 4.98 \mathrm{~g}, p<.05)$ and Diet $C(26.30 \pm 5.25 \mathrm{~g}, p<.05)$, but no significant

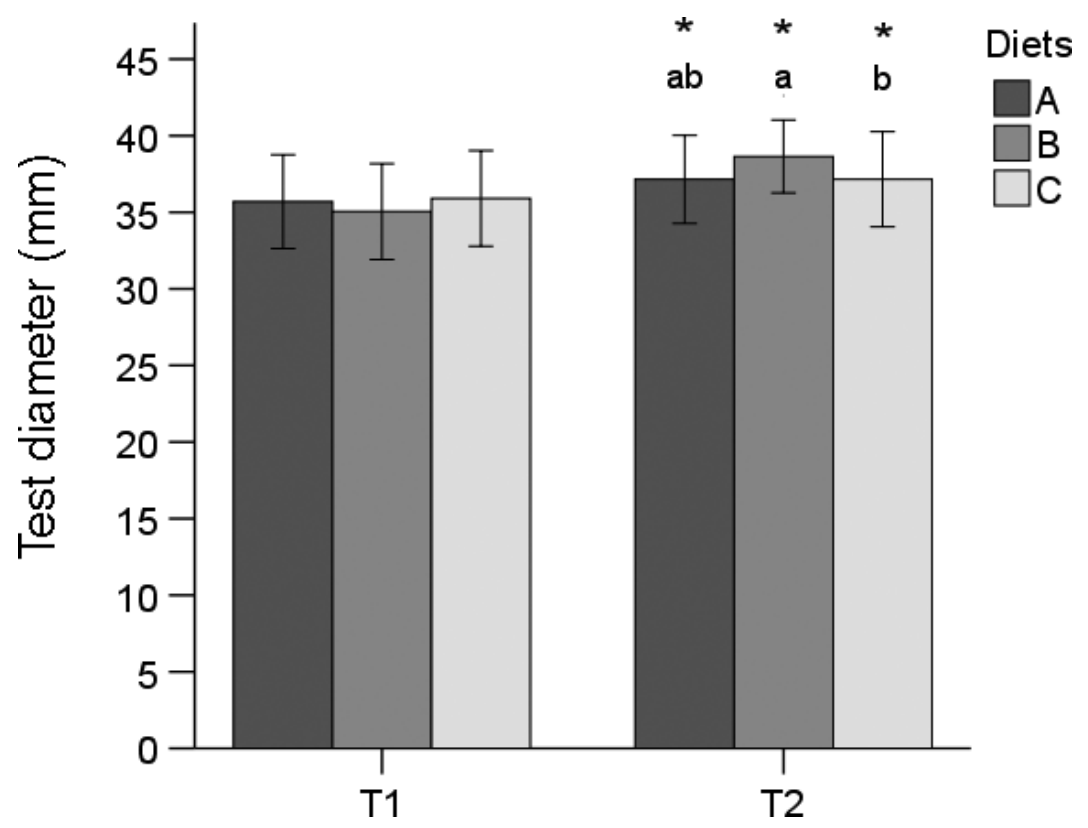

FIGURE 1 Test diameter (mean \pm SD) of Paracentrotus lividus in the beginning (T1) and at the end (T2) of the 90-day feeding trial, with three jellified diets. Diet A: maize, and spinach. Diet B: maize, spinach, and macroalga Laminaria digitata. Diet C: maize, spinach, and pumpkin Cucurbita maxima. Note: * represents statistically significant differences between time periods for each diet; for each time period, bars sharing the same letter are not significantly different according to Holm-Sidak's test 
differences were found between Diets $A$ and $C(p>.05)$. Furthermore, the individual total wet weight was distinct according to the time period considered $\left[F_{(1,264)}=70.564 ; p<.05\right]$ as the sea urchins grew significantly heavier from the beginning to the end of the trial [Diet A $(p<.05)$, Diet B $(p<.05)$, and Diet $C(p<.05)$ ]. No significant interaction time period $\times$ diet was found $\left[F_{(2,264)}=2.816 ; p>.05\right]$. Regarding the DGRs, the sea urchins from Diet $B$ grew faster $\left(0.30 \%\right.$ day $\left.^{-1}\right)$, followed by those from Diet C $\left(0.22 \%\right.$ day $\left.^{-1}\right)$ and Diet A $\left(0.17 \%\right.$ day $\left.^{-1}\right)$.

\section{3 | Gonadosomatic index}

The Gl values obtained at the end of the trial for each diet, as well as the mean Gl value of the 18 sea urchins sacrificed after the fasting period, are shown in Figure 3. The fasting period of 30 days led to a mean $\mathrm{Gl}$ value of $3.33 \%$. At the end of the 90-day feeding trial, there were significant differences between the Gl of individuals fed with the three different diets [one-way ANOVA: $F_{(2,132)}=10.283 ; p<.05$ ]. Sea urchins from Diet $A(9.07 \pm 2.39 \%)$ presented a higher value than those from Diet $B(7.17 \pm 1.99 \% ; p<.05)$ and Diet $C(7.31 \pm 2.26 \% p<.05)$, but no significant differences were observed between Diets B and C ( $p>$.05).

\subsection{Feed ingestion}

The total feed intake (Figure 4) presented significant differences between the three diets [Kruskal-Wallis test: $\left.H_{(2)}=81.594 ; p<.05\right]$. The feed intake for Diet $A\left(3.97 \pm 1.19 \mathrm{~g} \mathrm{day}^{-1}\right.$ ind $\left.^{-1}\right)$ was significantly lower than that for

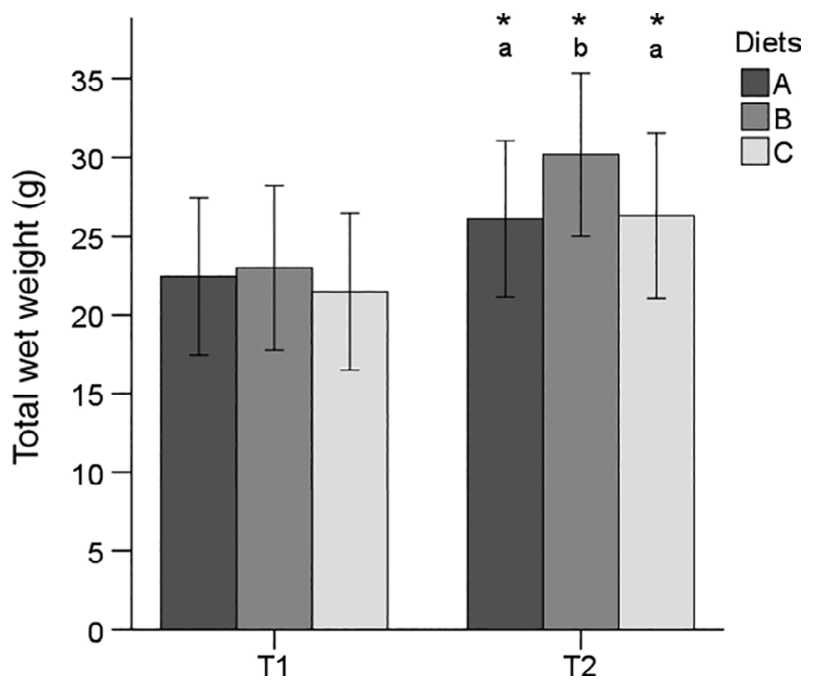

FIGURE 2 Total wet weight (mean \pm SD) of Paracentrotus lividus in the beginning (T1) and at the end (T2) of the 90-day feeding trial, with three jellified diets. Diet $A$ : maize and spinach. Diet B: maize, spinach, and macroalga Laminaria digitata. Diet C: maize, spinach, and pumpkin Cucurbita maxima. Note: * represents statistically significant differences between time periods for each diet; for each time period, bars sharing the same letter are not significantly different according to HolmSidak's test

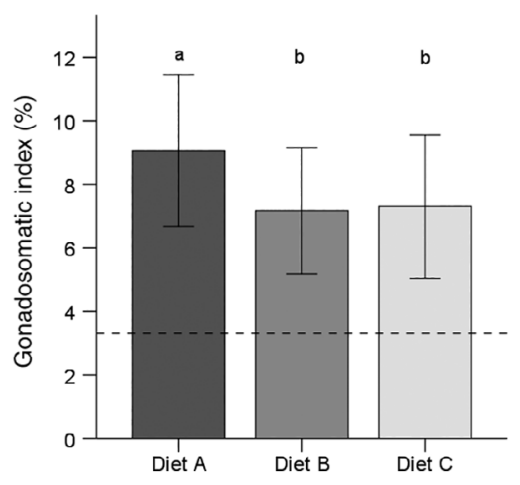

FIGURE 3 Gonadosomatic index (mean $\pm S D$ ) of Paracentrotus lividus at the end of the 90-day feeding trial, with three jellified diets. Diet A: maize and spinach. Diet B: maize, spinach, and macroalga Laminaria digitata. Diet C: maize, spinach, and pumpkin Cucurbita maxima. The average $\mathrm{Gl}$ of the 18 sacrificed individuals at the end of the fasting period is reported in the horizontal line (3.33\%). Note: Bars sharing the same letter are not significantly different according to Tukey's HSD test 
Diet $\mathrm{B}\left(5.44 \pm 1.36 \mathrm{~g} \mathrm{day}^{-1}\right.$ ind $\left.^{-1} ; p<.05\right)$ and Diet $\mathrm{C}\left(6.21 \pm 1.63 \mathrm{~g} \mathrm{day}^{-1}\right.$ ind $\left.^{-1} ; p<.05\right)$, just as the feed intake for Diet B was significantly lower when compared to diet C $(p<.05)$.

\subsection{Gender ratio and Gametogenic stages}

Regarding the gender ratio of the 18 individuals sacrificed at the end of the fasting period, 12 were females, and 6 were males (2:1). At the end of the feeding trial, there were 44 females and 46 males among the individuals sampled for histology (90 in total, 30 per diet), resulting in a ratio of $\approx 1: 1$. Figure 5 shows the relative frequencies of the different reproductive stages at the end of the fasting period and at the end of the feeding trial for each diet. After the fasting period of 30 days, $83.3 \%$ of the 18 sacrificed sea urchins were in the spent stage, $22.2 \%$ in stage I (spent with relict gametes), and $61.1 \%$ in stage $\mathrm{II}$ (spent empty). In relation to the remaining individuals, $11.1 \%$ were in stage VIII (postspawned) and 5.6\% in stage III (recovery).

After 90 days of rearing $P$. lividus on the three artificial diets, there was a significant development in the gonadal reproductive condition in sea urchins in all diets [goodness-of-fit chi-square tests: $\chi^{2}(7)=33.361, p<.05$ for Diet A; $\chi_{(7)}^{2}=36.797, p<.05$ for Diet $\mathrm{B}$; and $\chi^{2}(7)=28.513, p<.05$ for Diet $\mathrm{C}$ ], although there was no strong association between diets and gametogenic stages [chi-square test of association: $\chi^{2}{ }_{(14)}=10.876 ; p>.05$ ] at the end of the trial. At this time, the number of individuals in the spent condition (stages I and II) was significantly lower for the three diets: 13.3\% (Diet A), 6.7\% (Diet B), and 13.3\% (Diet C). For Diet B, 33.3\% of the individuals were still in recovery stage (stage III) in comparison to Diet A (with only $13.3 \%$ ) and Diet C (23.3\%). Stage III is characterized by small primary sexual cells but with a meshwork of NPs across the ascinus. Regarding the growing phase (stage IV), relative frequencies were similar between diets: 3.3\% (Diet A), 6.7\% (Diet B), and 3.3\% (Diet C). Diet A was the most successful in promoting maturation, with $20 \%$ of the sea urchins in the premature stage (V), already with mature gametes and able to spawn, and $46.7 \%$ in the mature stage (stage $\mathrm{VI}$ ). Therefore, $66.7 \%$ of the individuals from Diet $\mathrm{A}$ had

FIGURE 4 Feed intake (mean $\pm S D$ ) of Paracentrotus lividus during the 90-day feeding trial, with three artificial diets. Diet A: maize and spinach. Diet B: maize, spinach, and macroalga Laminaria digitata. Diet $C$ : maize, spinach, and pumpkin Cucurbita maxima. Note: Bars sharing the same letter are not significantly different according to MannWhitney $U$ test with Bonferroni correction

FIG URE 5 Reproductive condition of Paracentrotus lividus after 30 days of fasting and after 90 days of feeding with three artificial diets. Diet A: maize and spinach. Diet B: maize, spinach, and macroalga Laminaria digitata. Diet C: maize, spinach, and pumpkin Cucurbita maxima. Stages: I-spent with relict ova; II-spent empty; III-recovery; V-growing; V-premature; VI-mature; VII-partly spawned; and VIII-posts-pawned
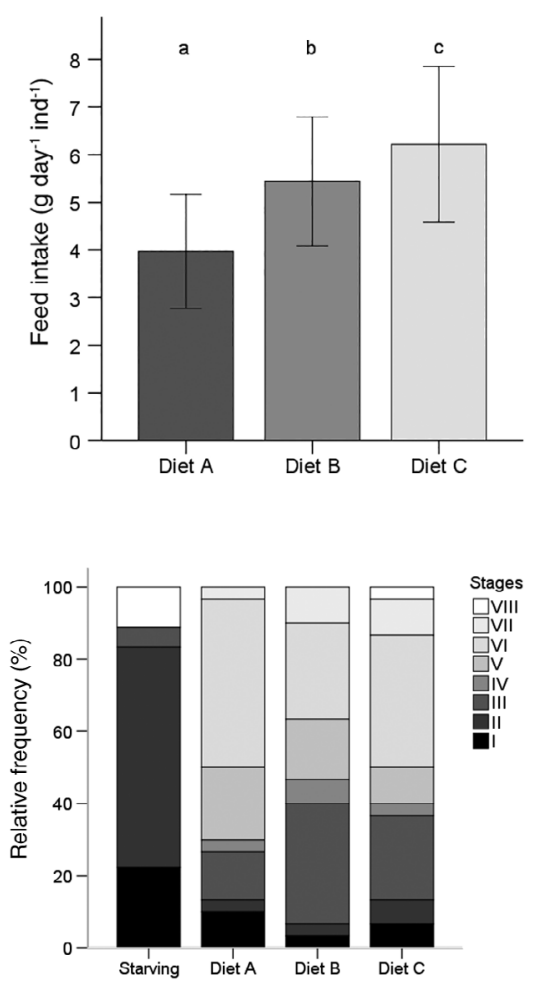
mature ova and spermatozoa. Diet C followed, with $46.7 \%$ of sea urchins containing mature gametes, specifically $10 \%$ in the premature stage $(\mathrm{V})$ and $36.7 \%$ in the mature stage $(\mathrm{VI})$. Finally, individuals in the mature stage (VI) only accounted for $26.7 \%$ of the sea urchins fed with Diet B, while $16.7 \%$ were in the premature stage (V). Few

(a)

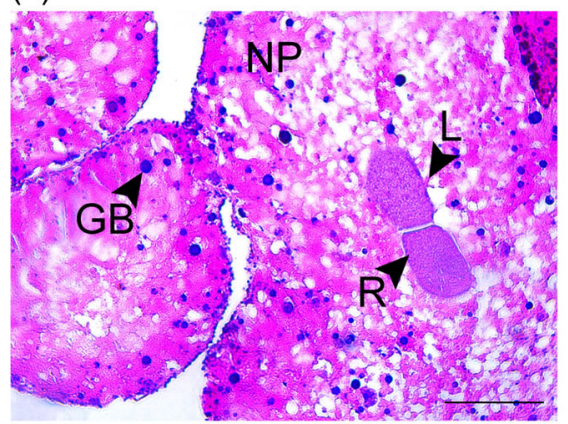

(c)

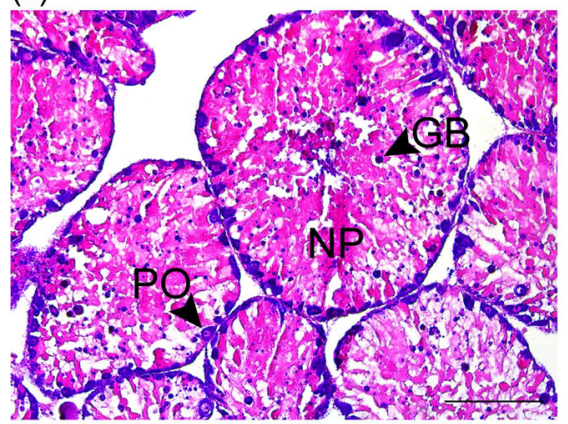

(e)

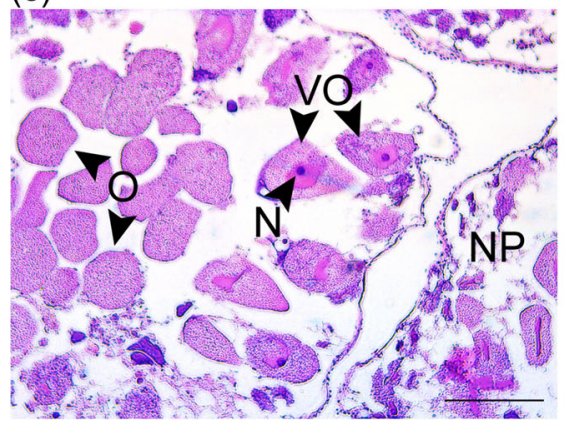

(g)

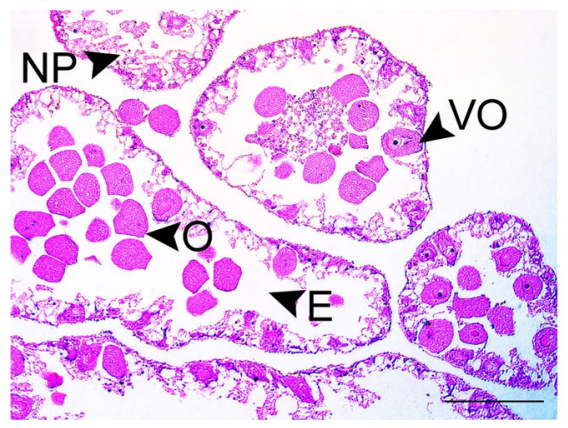

(b)

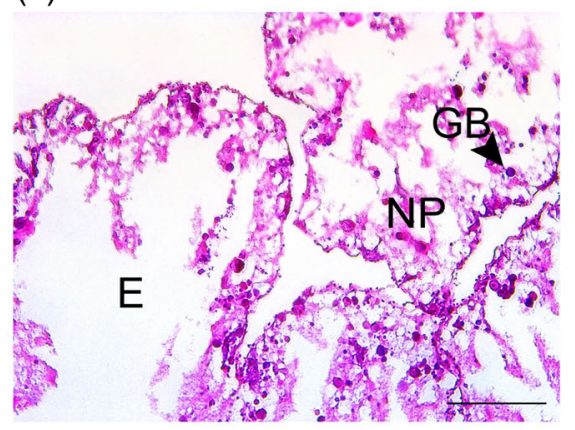

(d)

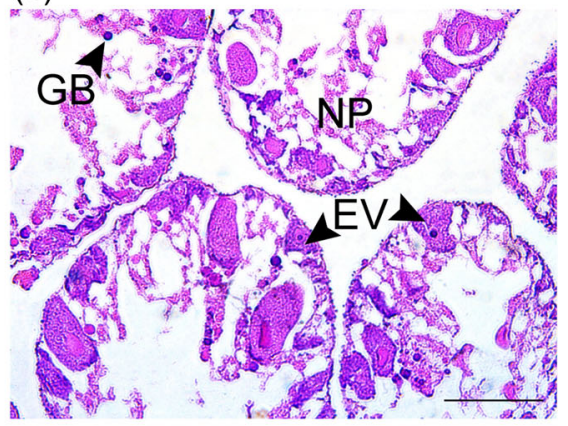

(f)

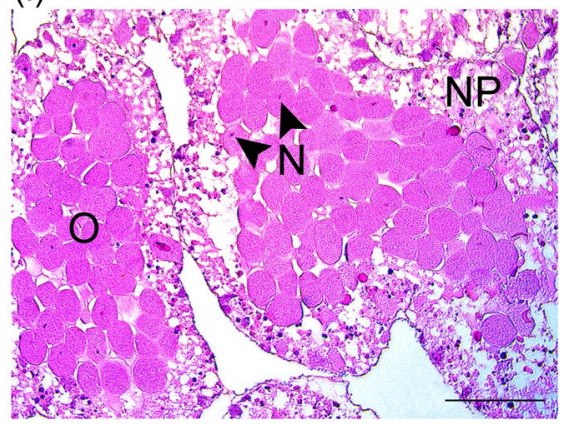

(h)

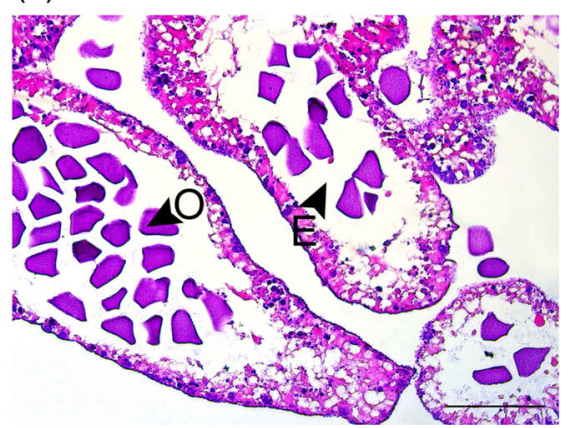

FIGURE 6 Legend on next page. 
individuals were observed in the partly spawned stage (VII), which is derived from the premature stage with the release of some gametes. Figures 6 and 7 illustrate all of the eight gametogenic stages, through histological analysis, of female and male individuals of $P$. lividus from the feeding trial.

\subsection{Oocyte/ova diameter}

Figure 8 represents the oocyte size-frequency distribution in the gonads of females fed with each of the three diets. The oocyte/ova diameter presented the following values for each diet: $55.331 \pm 22.276 \mu \mathrm{m}$ (Diet A), $46.149 \pm 26.529 \mu \mathrm{m}$ (Diet B), and $54.727 \pm 26.278 \mu \mathrm{m}$ (Diet C), with no significant differences between them [one-way ANOVA: $F_{(2,34)}=0.512 ; p>.05$ ]. Despite the similarity between the mean values for oocyte size of sea urchins reared on Diets $A$ and $C$, the results coincided with the relative frequencies of the gametogenic stages. Diet $A$ led to a major proportion of mature individuals, with large oocytes of $65-85 \mu \mathrm{m}$ in diameter as the most represented size class. It was followed by Diet C, which demonstrated a higher prevalence oocytes of the $70-80 \mu \mathrm{m}$ size class, although $22 \%$ correspond to the small size class of oocytes, with a diameter of between 10 and $20 \mu \mathrm{m}$. Figure 8 shows the presence of small oocytes in all diets, especially in Diets B and C, mainly associated with the recovery (III) and growing (IV) stages. Small oocytes of 10-25 $\mu \mathrm{m}$ diameter were the most numerous in Diet B.

\section{7 | Gonad color analysis}

The total CIELAB a* values of all sea urchin gonads from the three diets, regardless of gender, ranged from 129.96 to 160.94 [one-way ANOVA: $F_{(2,132)}=3.607 ; p<.05$ ]. As shown in Figure 9 , the gonads of individuals fed Diet $C$ $(144.42 \pm 5.45)$ were significantly redder than the gonads of the individuals fed Diet $B(141.47 \pm 5.74 ; p<.05)$, while those fed Diet A (141.78 \pm 5.98$)$ presented intermediate values $\left[p_{(\mathrm{A} \text { vs. B })}>.05 ; p_{(\mathrm{A} \text { vs. C) }}>.05\right]$.

Furthermore, after gender identification, a color assessment was also made between $P$. lividus fed with the different diets, separately for males and females. The mean a* parameter value for the female gonads (143.55 \pm 5.19$)$ was significantly higher than for the males [140.67 \pm 6.98 ; independent $t$-test: $\left.t_{(83)}=-2.224 ; p<.05\right]$. Regarding only female individuals, there were also significant differences in gonad color between diets [one-way ANOVA: $\left.F_{(2,41)}=3.399 ; p<.05\right]$ as Diet $C$ presented a more intense color than Diet $A(p<.05)$. On the other hand, the $a^{*}$ color parameter did not show significant differences between diets in relation to the male sea urchins [one-way

FIGURE 6 Histological sections of Paracentrotus lividus ovaries, conditioned by three artificial diets over a period of 90 days. Diet A: maize and spinach. Diet B: maize, spinach, and macroalga Laminaria digitata. Diet C: maize, spinach, and pumpkin Cucurbita maxima. (A) Stage I: cross-section through ascinus of late spent ovary with relict ova (R) being lysed and reabsorbed by the already formed meshwork of nutritive phagocytes (NP), with visible globules (GB), resulting from previous lysis of relict ova. (B) Stage Il: ovary in spent empty stage, with a thin ascinal wall, a pale meshwork of nutritive phagocytes, and empty lumen (E). (C) Stage III: recovering ovary, with clusters of previtellogenic oocytes (PO) along the ascinal wall; ascini are filled with a meshwork of nutritive phagocytes (NP), containing globules (GB). (D) Stage IV: ovary in growing stage, with early vitellogenic oocytes in contact with the ascinal wall (EV). (E) Stage V: premature ovary, containing oocytes in all stages of development, including vitellogenic oocytes (VO), with visible nucleus $(\mathrm{N})$ migrating toward the center, and ova $(\mathrm{O})$ accumulated in the lumen, displacing nutritive phagocytes. (F) Stage VI: ovary in mature stage, filled with closely aggregated ova and a thin layer of nutritive phagocytes along the ascinal wall. (G) Stage VII: partly spawned ovary, with empty spaces (E), resulting from spawned ova; oogenesis is still active, as in stage $\mathrm{V}$, with primary oocytes still maturing and mature ova in the lumen. (H) Stage VIII: ovary in post-spawned stage, with several empty spaces and the presence of several unspawned ova; the ascinal wall is now almost devoid of sexual cells or nutritive phagocytes (Hematoxylin-eosin stain. Scale bars: A, $B, D, E=100 \mu \mathrm{m} ; C, F, G, H=200 \mu \mathrm{m})$ 
(a)

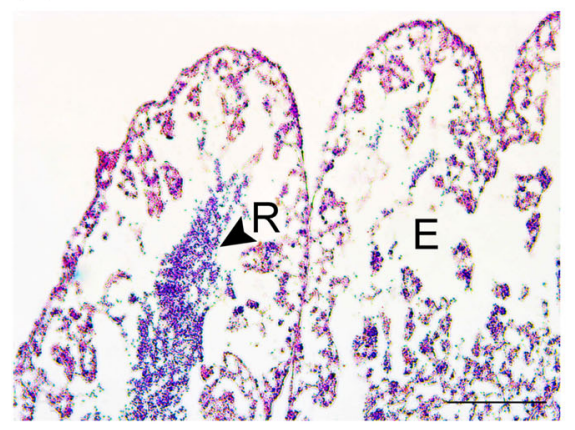

(c)

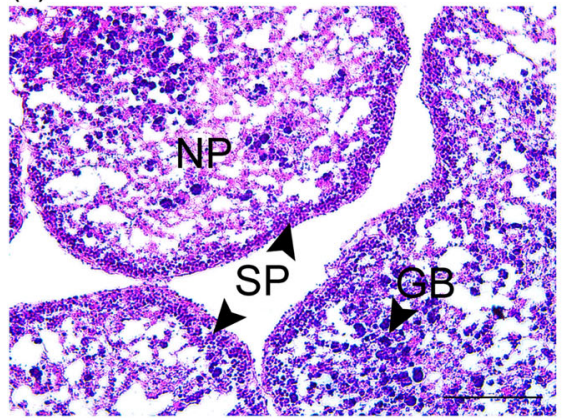

(e)

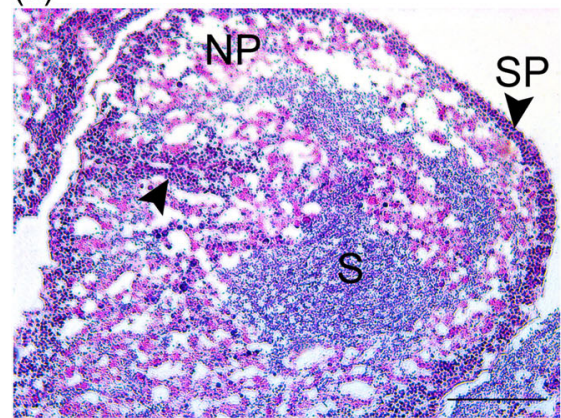

(g)

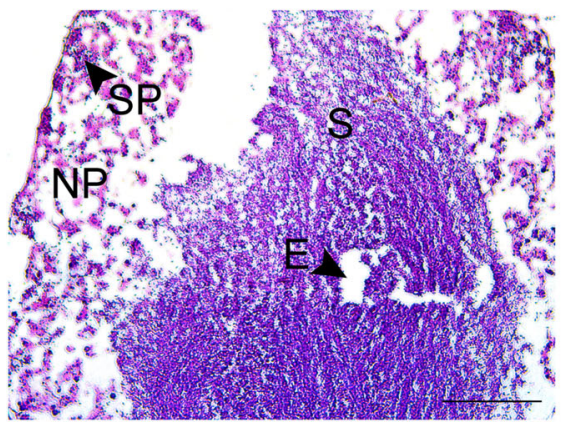

(b)

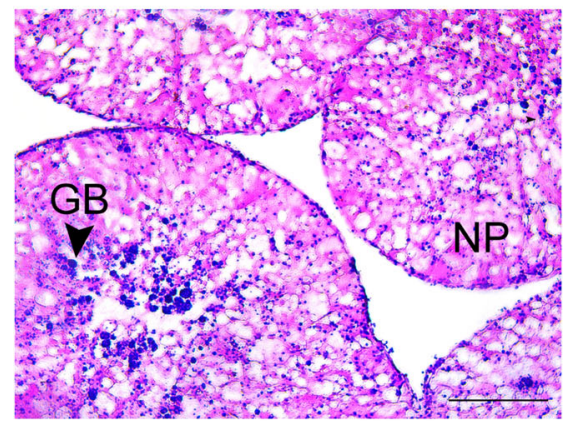

(d)

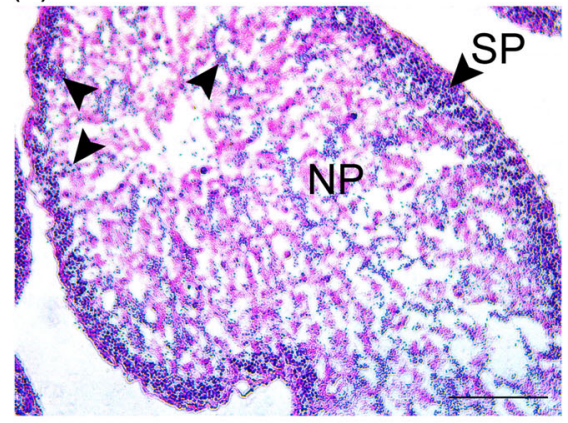

(f)

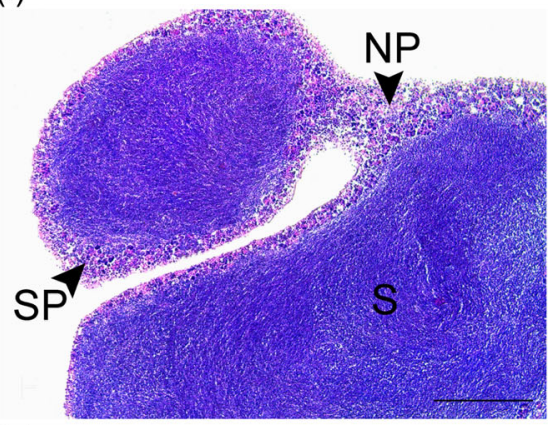

(h)

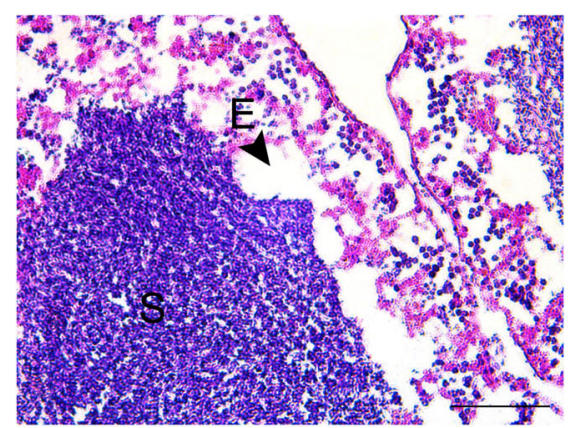

FIGURE 7 Legend on next page. 
FIGURE 8 Oocyte size-frequency distributions of Paracentrotus lividus females fed three artificial diets for 90 days. Diet A: maize and spinach. Diet $B$ : maize, spinach, and macroalga Laminaria digitata. Diet C: maize, spinach, and pumpkin Cucurbita maxima
FIGURE 9 Values of the a* color parameter (mean $\pm S D$ ) (according to the CIE color space) for all Paracentrotus lividus individuals fed with three artificial diets over a period of 90 days, as well as for males and females separately. Diet A: maize and spinach. Diet B: maize, spinach, and macroalga Laminaria digitata. Diet $\mathrm{C}$ : maize, spinach, and pumpkin Cucurbita maxima. Note: In each group, bars sharing the same letter are not significantly different according to Tukey's HSD test
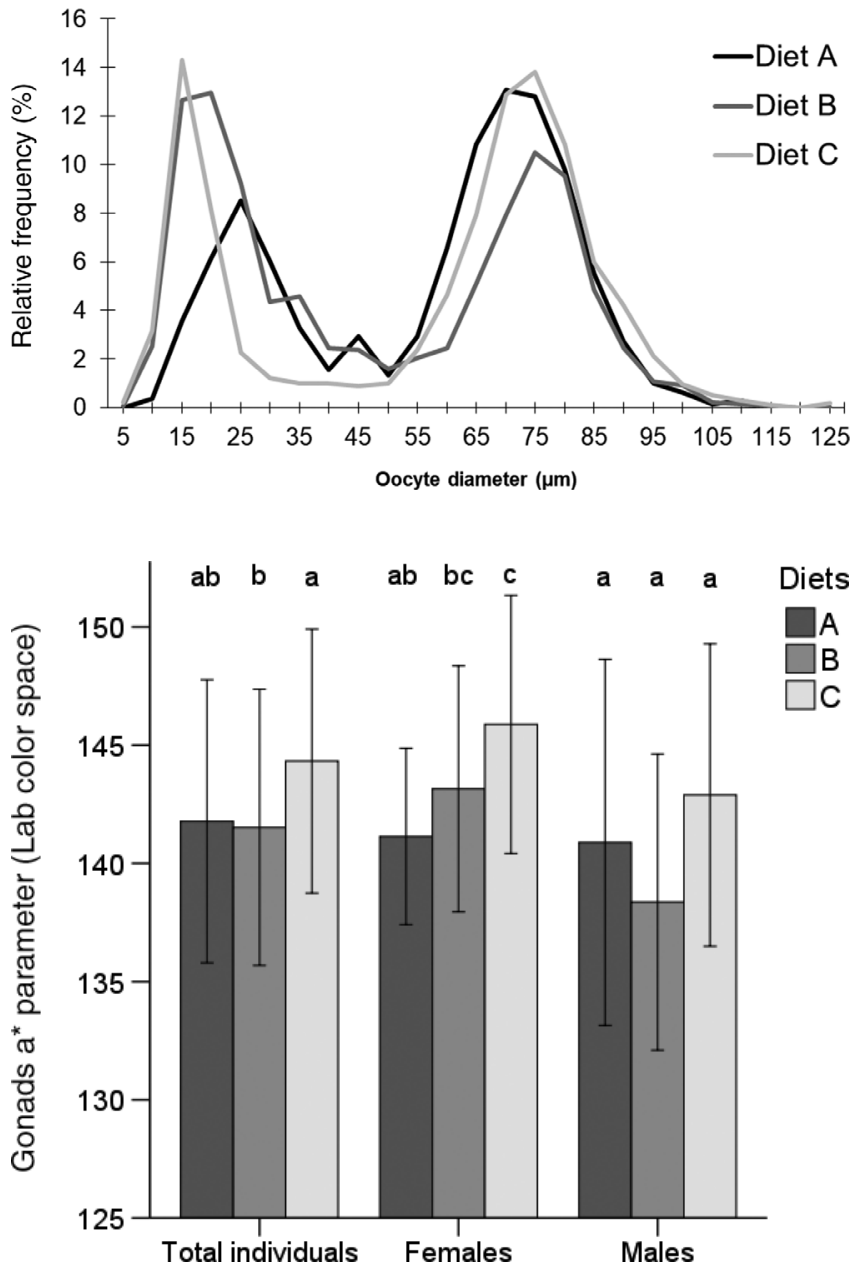

ANOVA: $F_{(2,43)}=1.578 ; p>$.05]. Figure 10 shows female and male gonads from each diet at the end of the feeding trial. It should be noted that the presented gonads are in different gametogenic stages of the reproductive cyclehence the presence of released fluid in mature gonads.

FIGURE 7 Histological sections of Paracentrotus lividus testes, conditioned by three artificial diets over a period of 90 days. Diet A: maize and spinach. Diet B: maize, spinach, and macroalga Laminaria digitata. Diet C: maize, spinach, and pumpkin Cucurbita maxima. (A) Stage I: cross-section of the ascinus from a spent testis with relict spermatozoa (R), mostly devoid of contents, presenting an empty lumen (E). (B) Stage II: testis in spent empty stage, already filled with a meshwork of nutritive phagocytes (NP), containing globules (GB) derived from relict spermatozoa; almost no spermatogonia are found in the ascinal wall. (C) Stage III: recovering testis, with a new layer of primary spermatocytes and spermatogonia (SP); several globules visible in the nutritive phagocytes. (D) Stage IV: testis in growing stage, with a thicker layer of spermatocytes (SP); columns of spermatocytes are visible, projecting centrally (arrows) through the NP meshwork. (E) Stage V: premature testis, with a very distinct column of spermatocytes (arrow) and mature spermatozoa (S) already accumulated in the lumen, displacing the NP. (F) Stage VI: mature testis, filled with spermatozoa and few nutritive phagocytes confined to the ascinus periphery; spermatogenesis is now only residual despite the presence of some spermatocytes. (G) Stage VII: testis in partly spawned stage, similar to stage $\mathrm{V}$, but with spaces $(\mathrm{E})$ in the lumen as a consequence of released spermatozoa. (H) Stage VIII: postspawned testis, with empty spaces between unspawned spermatozoa, and the ascinal wall is almost devoid of spermatogonia or NPs. (Hematoxylin-eosin stain. Scale bars: A, B, C, D, E, G = $100 \mu \mathrm{m}$; $\mathrm{F}=200 \mu \mathrm{m} ; \mathrm{H}=50 \mu \mathrm{m})$ 

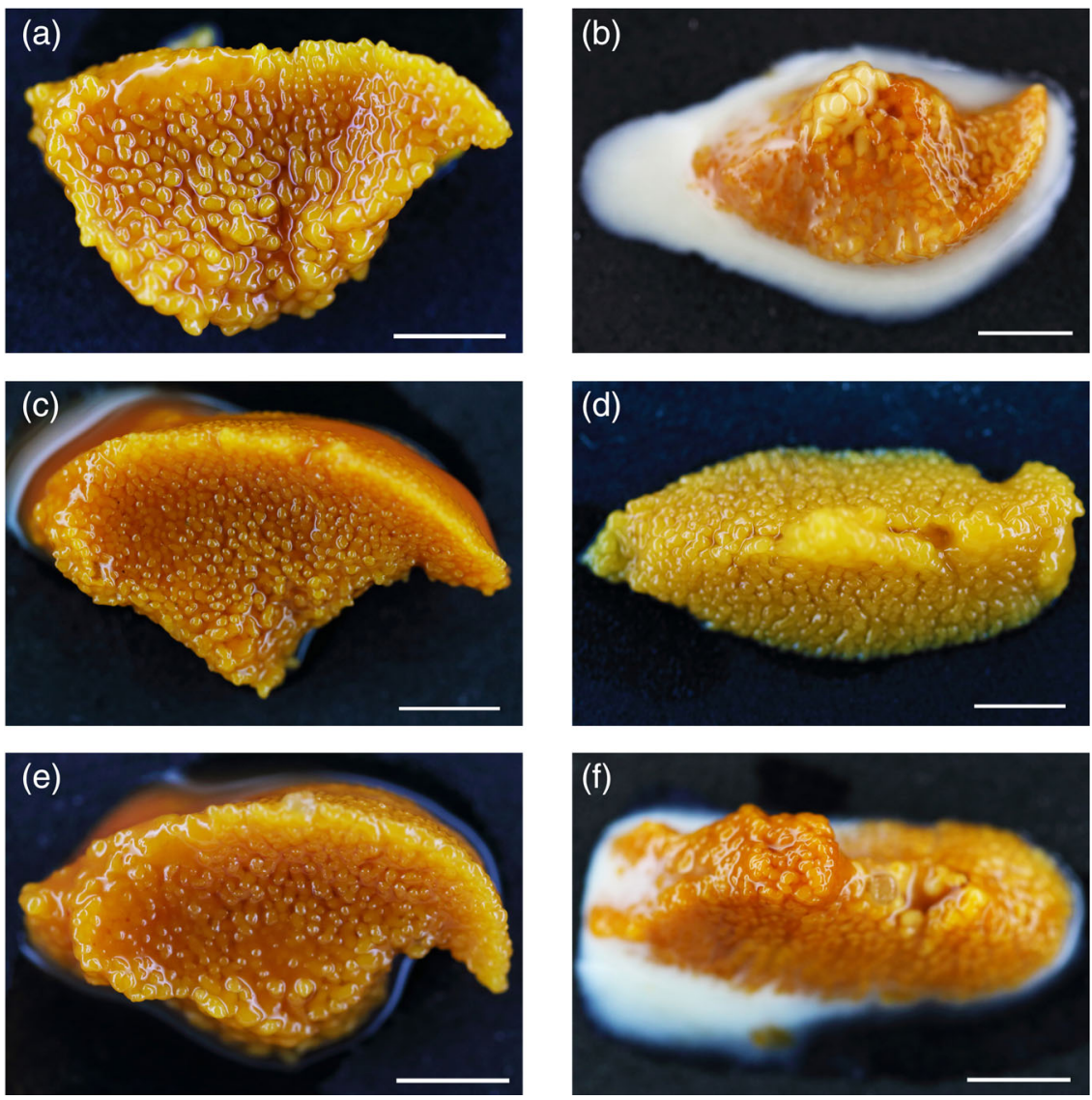

FIGURE 10 Photographs of gonads from Paracentrotus lividus reared with three artificial diets over a period of 90 days: Diet A (maize and spinach); Diet B (maize, spinach, and macroalga Laminaria digitata); Diet C (maize, spinach, and pumpkin Cucurbita maxima). (A) Ovary in stage VII from Diet A. (B) Testicle in stage VI from Diet A. (C) Ovary in stage VII from Diet B. (D) Testicle in stage III from Diet B. (E) Ovary in stage V from Diet C. (F) Testicle in stage VI from Diet C. (Scale bars: $A-F=0.65 \mathrm{~cm}$ )

\section{DISCUSSION}

For the development of echinoculture, it is crucial to find new artificial diets that are able to reduce the dependency on wild macroalgae and fishmeal, as well as to promote optimal growth and reproductive performances. The present study brings new perspectives for $P$. lividus aquaculture by comparing the effect of three jellified diets on somatic growth, $\mathrm{Gl}$, gonad coloration, and gametogenic development over a period of 90 days.

Regarding test diameter, the growth rates obtained with Diets A $\left(0.5 \mathrm{~mm}\right.$ month $\left.^{-1}\right)$ and C $\left(0.4 \mathrm{~mm} \mathrm{month}^{-1}\right)$ agreed with those obtained by Fernandez and Pergent (1998) for the same P. lividus size classes (30-45 mm). However, the growth obtained with Diet B (1.2 $\left.\mathrm{mm} \mathrm{month}^{-1}\right)$ was a particularly remarkable result, more common in smaller sea urchins (3-25 mm), in which the energy allocated for somatic growth (test and lantern) is higher, as shown by Cook and Kelly (2007a) and Cook and Kelly (2009). Growth rate in the Echinoidea class varies according to size (Fernandez \& Boudouresque, 2000; Turon, Giribet, López, \& Palacín, 1995) and according to the individual's physiology (Lawrence \& Lane, 1982) as there is a trade-off in allocating resources to somatic versus gonadal growth. According to previous studies, P. lividus' growth curves reach a stationary phase very early (Lawrence, 2007). Fernandez and Pergent (1998) inclusively stated that a diameter of $40 \mathrm{~mm}$ should be the maximum size limit for 
rearing $P$. lividus given the marked decrease in the growth rate (Shpigel et al., 2005). Regarding individual total wet weight, Diet B also promoted a similar/superior sea urchin weight gain when compared with the results of Frantzis and Grémare (1993), Basuyaux and Blin (1998), and Spirlet, Grosjean, and Jangoux (2001). These authors used smaller size classes of $P$. lividus, in addition to those of Shpigel et al. $(2004,2005)$, who fed these organisms with an extruded feed, and Cook and Kelly (2007a), who used fresh Laminaria sp. instead. Furthermore, Luo, Zhao, Chang, Feng, and Tian (2014) indicated that Strongylocentrotus intermedius (A. Agassiz, 1864) fed with kelp Laminaria japonica Areschoug, 1851 had a significantly higher body weight and test diameter than those fed with pumpkin Cucurbita sp., similar to the present work. Somatic growth rates in sea urchins are affected by water temperature and gonadal development but mainly by the quantity and quality of food available, as well as the organic matter they may ingest (Fernandez, 1996; Frantzis \& Grémare, 1993; Rowley, 1990). Although Fernandez and Pergent (1998) obtained the highest growth with a diet containing fishmeal, presumably as a consequence of a higher protein content (Fernandez \& Boudouresque, 2000), the present study achieved a significantly higher test diameter growth only with vegetable sources (maize, spinach, and L. digitata). According to Le Gall (1989), L. digitata is one of the algae species that enables consumption and growth rates that are acceptable for the aquaculture of $P$. lividus.

Given within-population variability (Byrne, 1990) in terms of gametogenesis (mainly between spermatogenesis and oogenesis), a probable asynchronous starting condition could substantially affect the results of feeding trial as the individuals were wild-caught (Cunningham, 2008; Mercurio \& Sugni, 2016). The fasting period of 30 days led to a Gl of $3.33 \pm 0.02 \%$ within the sacrificed individuals, mostly all in the spent stage, without natural or ensuing mortality occurring. This result was similar to Spirlet, Grosjean, and Jangoux (2000), Fabbrocini et al. (2015), Tomšić et al. (2015), and Sartori et al. (2016), corroborating the effectiveness of the procedure. After the 90-day feeding trial, all diets promoted gonadal growth, especially Diet A. As Gl or gonad yield represent the most important factors for aquaculture of sea urchins, it is reassuring that the results of this work were consistent with previous studies, in which artificial diets lead to a considerable increase in gonad yield (Fabbrocini \& D'Adamo, 2010; Fernandez \& Boudouresque, 2000; McBride, Price, Tom, Lawrence, \& Lawrence, 2004). Given the initial similarity in test diameter, total weight, and GI between the experimental sea urchins, the significant differences in the final results clearly demonstrated different allocation of nutrients given the somatic versus gonad growth duality (Spirlet et al., 2000). Energy is first allocated to maintenance and then to the digestive tract, and the remaining energy is shared between gonadal and somatic growth (Calow, 1981; Fernandez, 1996; Pearse \& Cameron, 1991). In this context, Diet A was the one with the highest allocation of resources to gonad growth, achieving a final Gl of $9.07 \pm 2.39 \%$, which represents an estimated $172.4 \%$ increase, despite having shown the weakest result in terms of individual total wet weight. Similarly, Fernandez and Boudouresque (2000), Luís et al. (2005), Repolho et al. (2011), Sartori and Gaion (2015), Sartori et al. (2015), Tomšić et al. (2015), and Sartori et al. (2016) reported high gonad yields with larger size classes and diets containing maize (even though these had no agar as a gelling agent). Despite the high allocation to somatic growth, Diet B showed the lowest Gl values of all the three treatments, with a final Gl of $7.17 \pm 1.99 \%$, corresponding to an estimated 115.3\% increase. Fernandez and Pergent (1998), Spirlet et al. (2001), Schlosser, Lupatsch, Lawrence, Lawrence, and Shpigel (2005), Shpigel et al. (2005), Fabbrocini et al. (2012), Carboni et al. (2015), Fabbrocini et al. (2015), Tomšić et al. (2015), and Sartori et al. (2016) also reported lower Gl in P. lividus fed with macroalgae diets. Regarding Diet C, a final Gl of $7.31 \pm 2.26 \%$, equivalent to an estimated $119.5 \%$ increase, was achieved. Interestingly, Luo et al. (2014) obtained the same relative results with S. intermedius. Although sea urchins fed with kelp had significantly higher gonad weight than those fed with pumpkin, the Gl from the pumpkin group was slightly higher (Luo et al., 2014). Given that Diet C in this study was also composed of $44 \%$ of maize and spinach, which alone (as in Diet A) promoted the best results in gonad yield, the inclusion of $C$. maxima seemed to be less effective. Apart from achieving a considerable gonadal growth rate with alternative feed sources (particularly with Diet A) and starting from a very low $\mathrm{Gl}$ after the fasting period, the final values obtained in this experimental trial were comparable to the ones observed in wild populations, which range between $6 \%$ and $12 \%$ (Spirlet et al., 2000). According to Spirlet et al. (1998a), wild populations of $P$. lividus in Brittany do not exceed a Gl of $8 \%$. This parameter 
tends to increase with sea urchin size (Fernandez \& Pergent, 1998), being the highest in the 40-70 mm size class rather than the 20-40 mm size class (Martínez, García, Sánchez, Daza, \& Castillo, 2003; Sánchez-España, MartínezPita, \& García, 2004). Therefore, the experimental sea urchin size class should be narrowed in the future according to the goal of the investigation. If the focus is on $P$. lividus reproduction, then the individuals should be selected with a test diameter above $40 \mathrm{~mm}$. In addition, the accumulation of nutrients by the NPs, as well as the accumulation of gametes, contribute to gonadal growth but in different degrees. Therefore, some variance in Gl could be expected given the different outcome in sexual maturation between the three diets, which corresponds to different ratios between germinative (sexual) and somatic (phagocytes) cells (Fabbrocini et al., 2012; Fernandez \& Pergent, 1998; Marsh \& Watts, 2007; Pearse \& Cameron, 1991; Unuma \& Walker, 2009).

The increase of gonad weight is mainly associated with the nutrients available and, thus, the quantity and quality of the feed ingested (Cuesta-Gomez \& Sánchez-Saavedra, 2014; Lawrence \& Lane, 1982). Proteins are regarded as the major dietary nutrient, with a high nutritional value, involved in reproduction. They contribute to an increase in somatic and gonadal growth rates, which occur through the accumulation of gametes and/or nutrients (Cook \& Kelly, 2007a; Fernandez \& Boudouresque, 2000; Jacquin et al., 2006). Jacquin et al. (2006) stated that the ideal protein level to optimize gonadal growth in P. lividus does not occur in the natural environment. Conversely, Cook and Kelly (2007b) suggested that $P$. lividus, as a herbivore, might be unable to digest high dietary protein levels in comparison to other omnivorous species. According to Marsh and Watts (2007), NPs show limited capacity for the assimilation of protein during an early growth stage, evidencing the large amount of energy that is also required for this process. Regarding the nutritional profile of maize dry matter (Zea mays), it has 12.9\% proteins, .9\% lipids, 1.5\% ash, $69.3 \%$ carbohydrate, and 9.5\% water (Cortez \& Wild-Altamirano, 1972). The high gonad yield of Diet A (maize $\&$ spinach) may be partly explained by the significant content of carbohydrates and proteins in maize when compared to spinach, algae, and pumpkin. Spinacia oleracea only has $2.1-2.6 \%$ protein, $0.38-0.9 \%$ lipids, $0.6 \%$ fiber, and $4 \%$ carbohydrates, with water as the main component (91\%) (Biehler, Kaulmann, Hoffmann, Krause, \& Bohn, 2011; Hanif, lqbal, Iqbal, Hanif, \& Rasheed, 2006). Macroalga L. digitata has an average protein content of $6.9 \%$, with significant seasonal variations (Schiener et al., 2015), plus 0.2-2\% lipids, 2.3-3.5\% fiber, 9-9.9\% carbohydrates, and 73-90\% water (Carboni et al., 2015). The chemical composition of the pumpkin C. maxima (fresh mesocarp) is: $1.13-2 \%$ protein, 0.42-0.5\% lipid content, 1.1\% fiber, 8-13.3\% carbohydrates, and 87.6\% water (Kim et al., 2012). Accordingly, the poor protein content of pumpkin may explain the lower output in gonadal and somatic growth of sea urchins fed Diet $C$ given that it contained $50 \%$ of this ingredient in its composition. In addition, Schlosser et al. (2005) suggested that energy may also play an important role in growth, namely, in the Gl, as a limiting factor during growing and

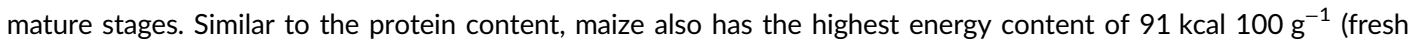
weight), followed by spinach with $27 \mathrm{kcal} 100 \mathrm{~g}^{-1}$ (fresh leaves), fresh L. digitata with $18 \mathrm{kcal} 100 \mathrm{~g}^{-1}$, and fresh pumpkin with $11 \mathrm{kcal} 100 \mathrm{~g}^{-1}$ (Carboni et al., 2015; Kim et al., 2012). Likewise, these values also support the highest gonad yield from Diet A, followed by Diet B and Diet C. In fact, if energy plays a more important role for gonad yield, maize is a very attractive alternative to the expensive extruded diets (Spirlet et al., 2001) as it has a high energy content (Luís et al., 2005).

Regarding ingestion rates, all sea urchins started feeding immediately after the fasting month, showing no need for an adaptation period and highlighting the generalist and opportunistic feeding behavior of $P$. lividus (Boudouresque \& Verlaque, 2007). Through the daily recovery and weighing of leftovers, it was noted that feeding was relatively constant through time, in all diets, as reported by Spirlet et al. (2001). The differences in ingestion between diets were certainly related to the chemical and physical properties of the feed (Carboni, 2013; Klinger, 1982), although its agar-based formulation was immediately accepted and readily consumed, as described by Fabbrocini et al. (2015). Therefore, palatability and attraction were successfully achieved, which are key factors for artificial feeds (Cirino, Ciaravolo, Paglialonga, \& Toscano, 2017; Cyrus, Bolton, Scholtz, \& Macey, 2015; Fabbrocini et al., 2015; Lawrence, Lawrence, \& Watts, 2013), as well as a suitable texture and form (Klinger, 1982; Spirlet et al., 2001). The inclusion of fresh triturated $L$. digitata in Diet B might have acted as a feeding stimulant, assuming its chemosensory characteristics were preserved (Cyrus et al., 2015; Klinger \& Lawrence, 1984). As the formulation 
method was the same for the three diets (6\% agar), it is easier to focus only on the nutritional aspect of the ingredients. In fact, food type affects ingestion rates in sea urchins as reported by Vadas (1977), Anderson and Velimirov (1982), De Ridder and Lawrence (1982), Frantzis and Grémare (1993), Fernandez and Pergent (1998), Fernandez and Boudouresque (2000), Cyrus et al. (2015), and Vizzini et al. (2015). Furthermore, protein levels seem to also be correlated to ingestion rates (Fernandez \& Boudouresque 1998). The present experiment is theoretically more in line with the compensatory food intake model (Frantzis, 1992), in which ingestion rates increase with low soluble protein levels as suggested by Frantzis and Grémare (1993) or Fernandez \& Boudouresque (1998). Feed rich in carbohydrates can be largely consumed to compensate for the low protein content (Carboni, 2013; Miller \& Mann, 1973) as what seemed to be the case in the present study. Accordingly, not only do vegetable feeds tend to increase ingestion rates (Fernandez \& Boudouresque 1998), but also, ad libitum feeding has the same effect (Minor \& Scheibling, 1997). Despite the high ingestion rate of Diet $C$, its output in gonadal growth was intermediate, probably because of its expected low protein content. Conversely, Diet $\mathrm{A}$ was the least consumed diet and promoted the highest gonadal yield as it contained more maize (47\%) than the other experimental diets-the ingredient richest in protein used in this work. Moreover, a diet rich in proteins and lipids also consumes more energy for its assimilation (Marsh \& Watts, 2007) and may reduce feed ingestion. Spirlet et al. (2001) achieved a higher intake of fresh Laminaria sp. in comparison to the more protein-rich extruded pellets. According to Spirlet et al. (1998b), although gonadal growth is correlated to feed intake (Fernandez, 1996), these are not directly proportional. Moreover, as maximal ingestion is dependent on physical constraints, such as the volume of the gut (Frantzis, 1992), the required protein levels for growth and maintenance might not be met. Furthermore, ingestion might also be related to physiological factors, such as the reproductive phase in adult individuals. The volume increase of the gonads in the coelomic cavity can reduce feeding rate and the superior energy requirements needed in the early stages of gametogenesis (Chang, Lawrence, Cao, \& Lawrence, 2005; Fabbrocini et al., 2012; Fernandez \& Boudouresque, 2000; Jacquin et al., 2006; Lawrence, 1975; Lawrence, Lawrence, \& Watts, 2007). Diet A was progressively less consumed through the trial, and it was also the diet that promoted the highest gonadal growth and maturation, exemplifying the latest assumptions.

The reproductive cycle of $P$. lividus has an annual pattern in the Mediterranean and Atlantic coasts, where gametogenesis normally occurs from September to May (Byrne, 1990; Fabbrocini \& D'Adamo, 2010; Lozano et al., 1995). However, in an artificial rearing system, the annual reproductive cycle of $P$. lividus tends to fade (Shpigel et al., 2004; Spirlet et al., 1998a), even more when fasting is used to eliminate seasonal reproductive conditions. The effectiveness of the fasting period was definitely corroborated as $83.3 \%$ of the individuals were in the spent stage (I and II), with no individuals in active gametogenesis, as reported by Spirlet et al. (2000), Fabbrocini and D'Adamo (2010), Fabbrocini et al. (2015), and Sartori and Gaion (2015). By starting to feed, sea urchins were able to store nutrients in the NPs and produce sexual cells, resuming the gametogenic cycle (Spirlet et al., 2001). The three diets promoted the progression of the reproductive cycle over a period of 90 days, in contrast to Shpigel et al. (2006) and Carboni et al. (2013). By this time, more than $60 \%$ of the individuals were in an active phase of gametogenesis (stages IVVII), although the recovery stage (III) could also be considered as it presents primary oocytes or primary spermatocytes in the ascinal wall, as described by Spirlet et al. (1998a). Diet A (maize and spinach) was the most successful in promoting maturation. Similarly, Luís et al. (2005) also obtained large spawning rates with a maize diet (dry grains), while Sartori and Gaion (2015) and Sartori et al. (2016) had the highest percentage of mature individuals with fresh maize and spinach, once again demonstrating the suitability of these ingredients to provide nutritional and energetic sources for gonadal growth and sexual maturation of P. lividus (Sartori et al., 2016). Conversely, Spirlet et al. (2001), Schlosser et al. (2005), Fabbrocini et al. (2012), and Sartori et al. (2016) also obtained a slower gametogenic progression with macroalgae diets, similar to Diet B (with $50 \%$ of L. digitata). The agar-based biocomposites seemed to promote a quick metabolic reaction, with the progression of the gametogenic cycle, attesting the feed quality and the advantage of allowing to choose and formulate ingredients according to specific nutritional requisites as reported by Russell (1998) and Fabbrocini et al. (2012). The most important analysis of these results is related to the desired goal of the rearing: good-quality gonads for the consumer (suppress or delay gametogenesis) or the production of mature gonads with viable gametes for seed stock. Therefore, the slower progression in the reproductive cycle promoted by 
Diet $B$ seems to be more appropriate for enhancement and consumption purposes as specimen synchronization to a desired gametogenic stage is easier. As some individuals had already formed mature gametes with this diet, a shorter rearing period could be applied. Conversely, the high output of gamete production from Diet C, and especially Diet A, highlights the suitability of maize (Luís et al., 2005), spinach, and also pumpkin for the enhancement of gametogenesis. Furthermore, as wild P. lividus populations in Portugal are only mature in mid-spring and summer, after accumulating reserves during winter (J. Gago et al., 2003), these diets allowed us to significantly modify the natural reproductive cycle because it is possible to obtain mature individuals at the end of the trial (in early February).

The oocyte diameter-frequency information corroborated the relative frequencies of the gametogenic stages present in each diet. Gonor (1973) reported that mature ovaries have a dominant class of large oocytes. Accordingly, the $60-90 \mu \mathrm{m}$ size class was presented as the most dominant (56\%) in females fed Diet A, mostly corresponding to large ova. Although Byrne (1990) indicates a large number of ova with a diameter of $90 \mu \mathrm{m}$ in the mature stage, $2 \%$ of the measured oocytes from Diet A were above this value. In addition, Lozano et al. (1995) considered mature ova with diameters above $70 \mu \mathrm{m}$ while studying natural populations of $P$. lividus, which is also in line with the present results. Given the presence of some females from Diet A in the recovery and growing stages, with primary oocytes surrounded by NPs, the size class of 15-30 $\mu \mathrm{m}$ was also abundant, similar to the findings of Byrne (1990) of primary oocytes of 5-30 $\mu \mathrm{m}$ in the recovery stage and 10-50 $\mu \mathrm{m}$ in the growing stage. Regarding Diet B, the majority of individuals was still in early stages of gametogenesis, thus leading to the dominance of the 10-25 $\mu \mathrm{m}$ size class (35\%), corresponding to primary oocytes attached to the ascinal wall of stages III and IV. However, $28 \%$ of the measured oocytes were 65-80 $\mu \mathrm{m}$ in diameter given the presence of premature and mature females. Finally, in Diet C, there was a predominance of oocytes of a diameter of $60-85 \mu \mathrm{m}(51 \%)$ in the significant percentage of premature/mature females. Still, $22 \%$ of the measured oocytes were between 10 and $20 \mu \mathrm{m}$ in diameter as maturation in Diet $\mathrm{C}$ was not so pronounced when compared to Diet A. It should be noted that premature (V), mature (VI), and partly spawned (VII) stages are characterized by the presence of various stages of oocyte development, particularly in stage $\mathrm{V}$.

Regarding the color analyses, the gonads of wild $P$. lividus range from pale yellow to dark brown, both colors being less appreciated for consumption purposes (Symonds, Kelly, Caris-Veyrat, \& Young, 2007). A bright yelloworange range represents the ideal color for market acceptance and high-priced gonads, considered an indication of great quality (Carboni, 2013; Senaratna, Evans, Southam, \& Tsvetnenko, 2005; Shpigel et al., 2006; Symonds et al., 2007). The gonad color derives mainly from the accumulation of carotenoid pigments (Carboni, 2013; Vizzini et al., 2015). Therefore, a carotenoid supplementation can substantially improve gonadal color in both genders (Plank, 2000). In general, echinenone ( $\alpha$ - and $\beta$-forms) and $\beta$-carotene represent the principal carotenoids in sea urchins (Fox \& Hopkins, 1966; Matsuno \& Tsushima, 2001; Symonds et al., 2007; Tsushima \& Matsuno, 1990), specifically with 9-cis echinenone as the dominant carotenoid in P. lividus (Symonds et al., 2007). $\beta$-echinenone and $\alpha$-echinenone are derived from dietary $\beta$-carotene and $\alpha$-carotene, respectively (Carboni et al., 2015; Cook \& Kelly, 2007a; Goodwin, 1984; Shpigel et al., 2005; Tsushima, Kawakami, \& Matsuno, 1993). Kelp is rich in the precursor $\beta$-carotene (Carboni et al., 2015; McDermid \& Stuercke, 2003) and increasing echinenone content is normally correlated with an intense and acceptable gonad coloration (Shpigel et al., 2005, 2006; Suckling, Symonds, Kelly, \& Young, 2011). A diet containing macroalgae (as Diet B) is thus expected to produce a high echinenone content and, therefore, decent coloration, as achieved by Shpigel et al. (2005, 2006) and Cook and Kelly (2009). Consequently, there is often the need to add natural algae to artificially formulated diets, prior to commercialization, in order to reliably achieve an acceptable coloration as reported by Cook, Kelly, and McKenzie (1998), Robinson, Castell, and Kennedy (2002), and Shpigel et al. (2005). Furthermore, Symonds et al. (2007) state that lipid content, or lutein levels, may also affect the visual perception of gonad color. In the present study, Diet B promoted better color results than Diet A when considering female individuals. Indeed, maize is rich in dietary xanthophylls, with lutein as the major carotenoid, followed by zeaxanthin (Janick-Buckner, Hammock, Johnson, Osborn, \& Buckner, 1999). These pigments are mostly related to fecundity, with little effect on gonad color (Kawakami et al., 1998; Lawrence, 2007; Plank, Lawrence, Lawrence, \& Olvera, 2002; Robinson et al., 2004; Tsushima et al., 1993). Likewise, the major carotenoid in spinach is lutein, followed by $\beta$-carotene, violaxanthin, and neoxanthin (Bunea et al., 2008). Moreover, $\beta$-carotene 
only accounts for $4-6 \%$ of total carotenoids in Laminaria sp., with all-trans fucoxanthin representing $80 \%$ (Haugan \& Liaaen-Jensen, 1994). In addition, the 9- or 9'-cis forms of carotenoids are absent in natural algae (Symonds et al., 2007). These factors may partly explain why Diet $C$ promoted the most successful color enhancement as its main carotenoid is $\beta$-carotene (>80\%), with lower levels of lutein, lycopene, $\alpha$-carotene, and-inclusively-cis- $\beta$-carotene (Seo, Burri, Quan, \& Neidlinger, 2005). Luo et al. (2014) reported that individuals fed pumpkin also attained a better gonad color acceptance, with slight differences from the kelp diet. Senaratna et al. (2005) and Vizzini et al. (2015) also obtained a commercially acceptable gonad coloration with vegetable sources. The different reproductive stages between diets may also affect gonad color. According to Symonds et al. (2007), low levels of echinenone and, therefore a paler coloration, coincide with pre- and actual spawning. Regarding the differences between males and females, female gonads not only contain more lutein and isozeaxanthin than males but also exclusively have ketocarotenoids, which possibly contribute to color differentiation, as observed by Symonds et al. (2007). In addition, these authors obtained an inferior $\beta$-carotene:echinenone ratio in female gonads, which may also imply a more intense color. However, it must be taken into account that sea urchin male sperm is white, while the female spawning fluid is orange/red (Lustres-Pérez, Rodríguez-Álvarez, Pata, Fernández-Pulpeiro, \& Cadarso-Suárez, 2010). Stress-induced spawning, while handling the specimens to analyze their gonads, might influence the visual perception. Notwithstanding, the areas covered in fluid were always avoided in the color analysis of the gonads, which did not impair the results obtained. Overall, gonad color in sea urchins can be easily modified through the use of different dietary carotenoids (Carboni, 2013) to reach the desired echinenone concentrations found in wild populations and craved by market demand (Carboni et al., 2015). As echinenone is not commercially available to be used in a formulated feed for sea urchins (Symonds et al., 2007), in addition to the need to reduce the dependency from wild macroalgae (Carboni, 2013), this study was able to emphasize the efficacy of accessible vegetable sources, particularly pumpkin, for color enhancement.

\section{5 | CONCLUSIONS}

The results obtained in this study demonstrated the suitability and efficiency of alternative food sources for the rearing of adult $P$. lividus in recirculating aquaculture systems (RAS). First, 1 month of fasting was, once again, proven to be a simple and effective method to obtain a mandatory sexual synchronization of the individuals. During the feeding trial (90 days), all three artificial diets promoted somatic and gonadal growth, without mortality, as well as the progression in the reproductive cycle from the spent stage to the last stages of gametogenesis. The formulated diets were promptly accepted by the sea urchins and easily manipulated. However, Diet B (maize, spinach, \& macroalga L. digitata) was the most successful regarding test diameter and individual total wet weight increase. Conversely, Diet A (maize and spinach) promoted the highest $\mathrm{Gl}$ and gonadal wet weight, even though it was the least consumed diet. Furthermore, Diet C (maize, spinach, and pumpkin C. maxima) led to the reddest coloration of the gonads, bringing new perspectives regarding the inclusion of carotenoids in a future commercial diet. Regarding the reproductive cycle, Diet A was the most efficient in promoting rapid sexual maturation, allowing us to obtain gametes in the winter, which is very unlikely in wild populations. On the other hand, Diet B proved to be more suited for consumption purposes given that the slower progression in the gametogenic cycle provided gonads in prematuration stages, concomitant with sensorial characteristics preferred by the consumers. Subsequently, the nutritive requirements of each reproductive or life stage should be studied in more detail to maximize the production according to the desired goal. Furthermore, it should also be noted that, given the nature of the experimental jellified diets created for this study, with high percentages of water, the results should be analyzed in the context of this experiment. In a future extruded commercial diet for P. lividus, including these ingredients, the aspects regarding growth, maturation, and coloration could certainly be optimized. Above all, the present results highlight the promising use of land vegetables and possible subproducts of this industry in artificial diets-in this case for a large-scale echinoculture, contributing to the circular economy and sustainability of the ecosystems. 


\section{ACKNOWLEDGMENTS}

This project was supported financially by the Operational Programme MAR2020 through the project 16-02-01-FMP-0004: Ouriceira Aqua: Aquaculture and Enhancement of Gonad Production in the Sea Urchin (Paracentrotus lividus). This study was also supported by Fundação para a Ciência e Tecnologia (FCT) through the strategic project UID/MAR/04292/2019 granted to MARE-Marine and Environmental Sciences Centre.

\section{ORCID}

\section{Ana Pombo (1D) https://orcid.org/0000-0003-1397-9206}

\section{REFERENCES}

Anderson, R. J., \& Velimirov, B. (1982). An experimental investigation of the palatability of kelp bed algae to the sea urchin Parechinus angulosus LESKE. Marine Ecology, 3, 357-373.

Atef, M., Rezaei, M., \& Behrooz, R. (2014). Preparation and characterization agar-based nanocomposite film reinforced by nanocrystalline cellulose. International Journal of Biological Macromolecules, 70, 537-544.

Barnes, D. K. A., \& Crook, A. C. (2001). Implications of temporal and spatial variability in Paracentrotus lividus populations to the associated commercial coastal fishery. Hydrobiologia, 465, 95-102.

Barnes, D. K. A., Verling, E., Crook, A., Davidson, I., \& O'Mahoney, M. (2002). Local population disappearance follows (20 yr after) cycle collapse in a pivotal ecological species. Marine Ecology Progress Series, 226, 311-313.

Basuyaux, O., \& Blin, J. L. (1998). Use of maize as a food source for sea urchins in a recirculating rearing system. Aquaculture International, 6(3), 233-247.

Basuyaux, O., \& Mathieu, M. (1999). Inorganic nitrogen and its effect on growth of the abalone Haliotis tuberculata Linnaeus and the sea urchin Paracentrotus lividus Lamarck. Aquaculture, 174(1), 95-107.

Bertocci, I., Domínguez, R., Machado, I., Freitas, C., Domínguez Godino, J., Sousa-Pinto, I., ... Gaspar, M. (2014). Multiple effects of harvesting on populations of the purple sea urchin Paracentrotus lividus in North Portugal. Fisheries Research, $150,60-65$

Biehler, E., Kaulmann, A., Hoffmann, L., Krause, E., \& Bohn, T. (2011). Dietary and host-related factors influencing carotenoid bioaccessibility from spinach (Spinacia oleracea). Food Chemistry, 125(4), 1328-1334.

Boudouresque, C. F., \& Verlaque, M. (2007). Ecology of Paracentrotus lividus. Developments in Aquaculture and Fisheries Science, 37, 243-285.

Britton, G., Liaaen-Jensen, G. S., \& Pfander, H. (Eds.). (2004). Carotenoids handbook. Basel, Switzerland: Birkhäuser Verlag.

Bronstein, O., Kroh, A., \& Loya, Y. (2016). Reproduction of the long-spined sea urchin Diadema setosum in the Gulf of Aqaba-implications for the use of gonad-indexes. Scientific Reports, 6(1), 29569.

Bunea, A., Andjelkovic, M., Socaciu, C., Bobis, O., Neacsu, M., Verhé, R., \& Van Camp, J. (2008). Total and individual carotenoids and phenolic acids content in fresh, refrigerated and processed spinach (Spinacia oleracea L.). Food Chemistry, 108 (2), 649-656.

Byrne, M. (1990). Annual reproductive cycles of the commercial sea urchin Paracentrotus lividus from an exposed intertidal and a sheltered subtidal habitat on the west coast of Ireland. Marine Biology, 104(2), 275-289.

Calow, P. (1981). Resource utilization and reproduction. In C. R. Townsend \& P. Calow (Eds.), Physiological ecology: An evolutionary approach to resource use (pp. 245-270). Oxford, England: Blackwell Science.

Carboni, S. (2013). Research and development of hatchery techniques to optimise juvenile production of the edible sea urchin, Paracentrotus lividus (Doctoral dissertation). University of Stirling, England.

Carboni, S., Addis, P., Cau, A., \& Atack, T. (2012). Aquaculture could enhance Mediterranean Sea urchin fishery, expand supply. The Global Aquaculture Advocate, 15(3), 44-45.

Carboni, S., Hughes, A. D., Atack, T., Tocher, D. R., \& Migaud, H. (2013). Fatty acid profiles during gametogenesis in sea urchin (Paracentrotus lividus): Effects of dietary inputs on gonad, egg and embryo profiles. Comparative Biochemistry and Physiology Part A: Molecular \& Integrative Physiology, 164(2), 376-382.

Carboni, S., Hughes, A. D., Atack, T., Tocher, D. R., \& Migaud, H. (2015). Influence of broodstock diet on somatic growth, fecundity, gonad carotenoids and larval survival of sea urchin. Aquaculture Research, 46(4), 969-976.

Carboni, S., Vignier, J., Chiantore, M., Tocher, D. R., \& Migaud, H. (2012). Effects of dietary microalgae on growth, survival and fatty acid composition of sea urchin Paracentrotus lividus throughout larval development. Aquaculture, 324, 250-258. 
Ceccherelli, G., Pais, A., Pinna, S., Sechi, N., \& Chessa, L. A. (2011). Human impact on Paracentrotus lividus: The result of harvest restrictions and accessibility of locations. Marine Biology, 158(4), 845-852.

Ceccherelli, G., Pinna, S., \& Sechi, N. (2009). Evaluating the effects of protection on Paracentrotus lividus distribution in two contrasting habitats. Estuarine, Coastal and Shelf Science, 81, 59-64.

Chang, Y. Q., Lawrence, J. M., Cao, X. B., \& Lawrence, A. (2005). Food consumption, absorption, assimilation and growth of the sea urchin Strongylocentrotus intermedius fed a prepared feed and the alga Laminaria japonica. Journal of the World Aquaculture Society, 36(1), 68-75.

Cirino, P., Ciaravolo, M., Paglialonga, A., \& Toscano, A. (2017). Long-term maintenance of the sea urchin Paracentrotus lividus in culture. Aquaculture Reports, 7, 27-33.

Cook, E. J., \& Kelly, M. S. (2007a). Enhanced production of the sea urchin Paracentrotus lividus in integrated open-water cultivation with Atlantic salmon Salmo salar. Aquaculture, 273(4), 573-585.

Cook, E. J., \& Kelly, M. S. (2007b). Effect of variation in the protein value of the red macroalga Palmaria palmata on the feeding and growth of the sea urchins Psammechinus miliaris and Paracentrotus lividus (Echinodermata). Aquaculture, 270, 207-217.

Cook, E. J., \& Kelly, M. S. (2009). Co-culture of the sea urchin Paracentrotus lividus and the edible mussel Mytilus edulis L. on the west coast of Scotland, United Kingdom. Journal of Shellfish Research, 28(3), 553-559.

Cook, E. J., Kelly, M. S., \& McKenzie, J. D. (1998). Somatic and gonadal growth of the sea urchin Psammechinus miliaris (Gmelin) fed artificial salmon feed compared with a macro algal diet. Journal of Shellfish Research, 17, 1549-1555.

Cortez, A., \& Wild-Altamirano, C. (1972). Contributions to the lime treated corn flour technology. In R. Bressani, J. E. Braham, \& M. Behar (Eds.), Nutritional improvement of maize (pp. 99-106). Guatemala: INCAP Pub. L4.

Cuesta-Gomez, D. M., \& Sánchez-Saavedra, M. (2014). Increased gonad growth of the purple sea urchin (Strongylocentrotus purpuratus) fed the giant kelp (Macrocystis pyrifera) and the sea lettuce (Ulva lactuca) enriched with nutrients. Aquaculture Research, 47(7), 2150-2163.

Cunningham, A. (2008). The reproductive cycle of Lytechinus variegatus (Echinodermata: Echinoidea) from the Florida panhandle (Doctoral dissertation). University of Alabama, Birmingham, AL.

Cyrus, M. D., Bolton, J. J., Scholtz, R., \& Macey, B. M. (2015). The advantages of Ulva (Chlorophyta) as an additive in sea urchin formulated feeds: Effects on palatability, consumption and digestibility. Aquaculture Nutrition, 21(5), 578-591.

De Ridder, C., \& Lawrence, J. M. (1982). Food and feeding mechanisms: Echinoidea. In M. Jangoux \& J. M. Lawrence (Eds.), Echinoderm nutrition (pp. 57-116). Rotterdam, The Netherlands: A.A. Balkema.

Domínguez, R., Godino, J. D., Freitas, C., Machado, I., \& Bertocci, I. (2015). Habitat traits and patterns of abundance of the purple sea urchin, Paracentrotus lividus (Lamarck, 1816), at multiple scales along the north Portuguese coast. Estuarine, Coastal and Shelf Science, 155, 47-55.

Fabbrocini, A., \& D'Adamo, R. (2010). Gamete maturation and gonad growth in fed and starved sea urchin Paracentrotus lividus (Lamarck, 1816). Journal of Shellfish Research, 29(4), 1051-1059.

Fabbrocini, A., Volpe, M. G., Coccia, E., D'Adamo, R., \& Paolucci, M. (2015). Agar-based biocomposites slow down progression in the reproductive cycle facilitating synchronization of the gonads of reared specimens of Paracentrotus lividus. International journal of aquaculture and fishery. Sciences, 1(2), 035-041.

Fabbrocini, A., Volpe, M. G., Di Stasio, M., D'Adamo, R., Maurizio, D., Coccia, E., \& Paolucci, M. (2012). Agar-based pellets as feed for sea urchins (Paracentrotus lividus): Rheological behaviour, digestive enzymes and gonad growth. Aquaculture Research, 43(3), 321-331.

FAO (Food \& Agriculture Organization) (2012) The state of world fisheries and aquaculture (SOFIA) 2012. Rome, Italy, p. 209.

FAO (Food \& Agriculture Organization) (2013) FAO-Fisheries and aquaculture information and statistics service. Retrieved from www.fao.org/fishery/statistics/en

FAO (Food \& Agriculture Organization) (2016) The state of world fisheries and aquaculture 2016. Contributing to Food Security and Nutrition for all. Rome, Italy, p. 200.

FAO (Food \& Agriculture Organization). (2018). FAO year book: Fishery and aquaculture statistics 2016 (p. 104). Rome, Italy: Food and Agriculture Organization of the United Nations.

Fernandez, C. (1996) Croissance et nutrition de Paracentrotus lividus dans le cadre d'un projet aquacole avec alimentation artificielle (Doctoral dissertation). Université de Corse, Corte, France.

Fernandez, C. (1997). Effect of diet on the biochemical composition of Paracentrotus lividus (Echinodermata: Echinoidea) under natural and rearing conditions (effect of diet on biochemical composition of urchins). Comparative Biochemistry and Physiology-Part A, 118(4), 1377-1384.

Fernandez, C., \& Boudouresque, C. F. (1998). Evaluating artificial diets for small Paracentrotus lividus (Echinodermata: Echinoidea). In R. Mooi, \& M. Telford. (Eds.), Echinoderms: San Francisco (pp. 651-656). Rotterdam: Balkema.

Fernandez, C., \& Boudouresque, C. F. (2000). Nutrition of the sea urchin Paracentrotus lividus (Echinodermata: Echinoidea) fed different artificial food. Marine Ecology Progress Series, 204, 131-141. 
Fernandez, C., \& Pergent, G. (1998). Effect of different formulated diets and rearing conditions on growth parameters in the sea urchin Paracentrotus lividus. Journal of Shellfish Research, 17, 1571-1582.

Fox, D. L., \& Hopkins, T. S. (1966). The comparative biochemistry of pigments. In R. A. Boolootian (Ed.), Physiology of echinodermata (pp. 277-300). New York, NY: Interscience.

Frantzis, A. (1992) Etude expérimentales des niveaux de consommation et d'utilisation des macrophytes et des détritus dérivés par deux invertébrés benthiques: Paracentrotus lividus (Echinoide, herbivore) et Abra ovata (Bivalve, dépositivore) (Doctoral dissertation). Université Aix-Marseille II, France.

Frantzis, A., \& Grémare, A. (1993). Ingestion, absorption, and growth rates of Paracentrotus lividus (Echinodermata: Echinoidea) fed different macrophytes. Marine Ecology Progress Series, 95, 169-183.

Gago, J., \& Luís, O. J. (2010). Stocking density and captive sea urchin Paracentrotus lividus (Lamarck, 1816) gamete production and fertilization. Journal of Shellfish Research, 29(2), 513-516.

Gago, J., \& Luís, O. J. (2011). Comparison of spawning induction techniques on Paracentrotus lividus (Echinodermata: Echinoidea) broodstock. Aquaculture International, 19(1), 181-191.

Gago, J., Martins, T., Luís, O. J., \& Pousão-Ferreira, P. (2010). Survival and growth of selected marine fish larvae first fed with eggs and endotrophic larvae of the sea urchin Paracentrotus lividus. Aquaculture Research, 41(9), 96-108.

Gago, J., Range, P., \& Luís, O. J. (2003). Growth, reproductive biology and habitat selection of the sea urchin Paracentrotus lividus in the coastal waters of Cascais, Portugal. In J. P. Féral \& B. David (Eds.), Echinoderm research (pp. 269-276). Lisse, Netherlands: A.A. Balkema Press.

Gago, J. M., Luís, O. J., \& Repolho, T. R. (2009). Fatty acid nutritional quality of sea urchin Paracentrotus lividus (Lamarck 1816) eggs and endotrophic larvae: Relevance for feeding of marine larval fish. Aquaculture Nutrition, 15(4), 379-389.

Ghisaura, S., Loi, B., Biosa, G., Baroli, M., Pagnozzi, D., Roggio, T., ... Addis, M. F. (2016). Proteomic changes occurring along gonad maturation in the edible sea urchin Paracentrotus lividus. Journal of Proteomics, 144, 63-72.

Gonor, J. J. (1973). Reproductive cycles in oregon populations of the echinoid, Strongylocentrotus purpuratus (Stimpson). I. Annual gonad growth and ovarian gametogenic cycles. Journal of Experimental Marine Biology and Ecology, 12(1), 45-64.

Goodwin, T. W. (1984). The biochemistry of the carotenoids, Vol. II. Animals. London, England: Chapman \& Hall.

Grosjean, P., Spirlet, C., Gosselin, P., Vaitilingon, D., \& Jangoux, M. (1998). Land-based, closed cycle Echinoculture of Paracentrotus lividus (Lamarck) (Echinoidea: Echinodermata): A long-term experiment at a pilot scale. Journal of Shellfish Research, 17(5), 1523-1531.

Grosjean, P., Spirlet, C., \& Jangoux, M. (2003). A functional growth model with intraspecific competition applied to a sea urchin, Paracentrotus lividus. Canadian Journal of Fisheries and Aquatic Sciences, 60(3), 237-246.

Guidetti, P., Terlizzi, A., \& Boero, F. (2004). Effects of the edible sea urchin, Paracentrotus lividus, fishery along the Apulian rocky coast (SE Italy, Mediterranean Sea). Fisheries Research, 66(2-3), 287-297.

Hagen, N. T. (1996). Echinoculture: From fishery enhancement to closed cycle cultivation. Journal of the World Aquaculture Society, 27, 6-19.

Hanif, R., Iqbal, Z., Iqbal, M., Hanif, S., \& Rasheed, M. (2006). Use of vegetables as nutritional food: Role in human health. Journal of Agricultural and Biological Science, 1(1), 18-20.

Hardy, R. W., \& Tacon, A. G. (2002). Fish meal: Historical uses, production trends and future outlook for sustainable supplies. In R. R. Stickney \& J. P. MacVey (Eds.), Responsible marine aquaculture (pp. 311-325). New York, NY: CABI.

Harrington, L. H., Walker, C. W., \& Lesser, M. P. (2007). Stereological analysis of nutritive phagocytes and gametogenic cells during the annual reproductive cycle of the green sea urchin, Strongylocentrotus droebachiensis. Invertebrate Biology, 126 (2), 202-209.

Hatlen, B., Jobling, M., \& Bjerkeng, B. (1998). Relationships between carotenoid concentration and colour of fillets of Arctic chair, Salvelinus alpinus (L.), fed astaxanthin. Aquaculture Research, 29(3), 191-202.

Haugan, J. A., \& Liaaen-Jensen, S. (1994). Algal carotenoids 54. Carotenoids of brown algae (Phaeophyceae). Biochemical Systematics and Ecology, 22, 31-41.

Heflin, L. E., Makowsky, R., Taylor, J. C., Williams, M. B., Lawrence, A. L., \& Watts, S. A. (2016). Production and economic optimization of dietary protein and carbohydrate in the culture of Juvenile Sea Urchin Lytechinus variegatus. Aquaculture, 463, 51-60.

Hu, B., Cline, D., Davis, A., Wang, Y., \& Liu, S. (2015). Validation of xanthophyll levels in catfish fillets using digital photography. Journal of Aquatic Food Product Technology, 24(7), 723-729.

Jacinto, D., Bulleri, F., Benedetti-Cecchi, L., \& Cruz, T. (2013). Patterns of abundance, population size structure and microhabitat usage of Paracentrotus lividus (Echinodermata: Echinoidea) in SW Portugal and NW Italy. Marine Biology, 160(5), 1135-1146.

Jacquin, A. G., Donval, A., Guillou, J., Leyzour, S., Deslandes, E., \& Guillou, M. (2006). The reproductive response of the sea urchins Paracentrotus lividus (G.) and Psammechinus miliaris (L.) to a hyperproteinated macrophytic diet. Journal of Experimental Marine Biology and Ecology, 339(1), 43-54. 
Janick-Buckner, D., Hammock, D. J., Johnson, J. M., Osborn, J. M., \& Buckner, B. (1999). Biochemical and ultrastructural analysis of the $y 10$ mutant of maize. Journal of Heredity, 90(5), 507-513.

Kawakami, T., Tsushima, M., Katabami, Y., Mine, M., Ishida, A., \& Matsuno, T. (1998). Effect of $\beta$, $\beta$-carotene, $\beta$-echinenone, astaxanthin, fucoxanthin, vitamin a and vitamin $\mathrm{E}$ on the biological defense of the sea urchin Pseudocentrotus depressus. Journal of Experimental Marine Biology and Ecology, 226(2), 165-174.

Kim, M. Y., Kim, E. J., Kim, Y. N., Choi, C., \& Lee, B. H. (2012). Comparison of the chemical compositions and nutritive values of various pumpkin (Cucurbitaceae) species and parts. Nutrition Research and Practice, 6(1), 21-27.

Klinger, T. S. (1982). Feeding rates of Lytechinus variegatus Lamarck (Echinodermata: Echinoidea) on differing physiognomies of an artificial food of uniform composition. In J. M. Lawrence (Ed.), Echinoderms: Proceedings of the international conference (pp. 29-32). Rotterdam, The Netherlands: Tampa Bay. Balkema Press.

Klinger, T. S., \& Lawrence, J. M. (1984). Phagostimulation of Lytechinus variegatus (Lamarck) (Echinodermata: Echinoidea). Marine and Freshwater Behaviour and Physiology, 11, 49-67.

Lawrence, J. M. (1975). On the relationships between marine plants and sea-urchins. Oceanography and Marine Biology, 13, 213-286.

Lawrence, J. M. (2007). Edible Sea urchins: Use and life-history strategies. Developments in Aquaculture and Fisheries Science, 37, 1-9.

Lawrence, J. M., \& Lane, J. M. (1982). The utilization of nutrients by post-metamorphic echinoderms. In M. Jangoux \& J. M. Lawrence (Eds.), Echinoderm nutrition (pp. 331-371). Rotterdam, The Netherlands: Balkema.

Lawrence, J. M., Lawrence, A. L., \& Watts, S. A. (2007). Feeding, digestion and digestibility. In J. M. Lawrence (Ed.), Edible sea urchins: Biology and ecology (2nd ed., pp. 135-158). Amsterdam, The Netherlands: Elsevier B.V..

Lawrence, J. M., Lawrence, A. L., \& Watts, S. A. (2013). Feeding, digestion and digestibility of sea urchins. In J. M. Lawrence (Ed.), Sea urchins: Biology and ecology (pp. 135-154). Amsterdam, The Netherlands: Elsevier B.V..

Le Gall, P. (1989). Echinoculture. In G. Barnabé (Ed.), Aquaculture (pp. 468, 1-491). Paris, France: Lavoisier Tech and Doc.

Le Gall, P. (1990). Culture of echinoderms. In G. Barnabé (Ed.), Aquaculture (Vol. 1, pp. 443-462). New York, NY: Ellis Horwood Press.

Li, P. F., Ning, Y. W., \& Jing, J. F. (2017). Research on the detection of fabric color difference based on T-S fuzzy neural network. Color Research \& Application, 42, 609-618.

Lozano, J., Galera, J., López, S., Turon, X., Palacin, C., \& Morera, G. (1995). Biological cycles and recruitment of Paracentrotus lividus (Echinodermata: Echinoidea) in two contrasting habitats. Marine Ecology Progress Series, 122, 179-192.

Luís, O., Delgado, F., \& Gago, J. (2005). Year-round captive spawning performance of the sea urchin Paracentrotus lividus: Relevance for the use of its larvae as live feed. Aquatic Living Resources, 18(1), 45-54.

Luo, S., Zhao, C., Chang, Y., Feng, W., \& Tian, X. (2014). Banana peel provides a new insight into improving gonad flavor in the sea urchin Strongylocentrotus intermedius. Aquaculture International, 22(2), 833-841.

Lustres-Pérez, V., Rodríguez-Álvarez, M. X., Pata, M. P., Fernández-Pulpeiro, E., \& Cadarso-Suárez, C. (2010). Application of receiver operating characteristic (ROC) methodology in biological studies on marine resources: Sex determination of Paracentrotus lividus (Lamarck, 1816). SORT-Statistics and Operations Research Transactions, 34(2), 239-248.

Marsh, A. G., \& Watts, S. A. (2007). Biochemical and energy requirements of gonad development. Developments in Aquaculture and Fisheries Science, 37, 35-53.

Martínez, I., García, F. J., Sánchez, A. I., Daza, J. L., \& Del Castillo, F. (2003). Biometric parameters and reproductive cycle of Paracentrotus lividus (Lamarck) in three habitats of southern Spain. In J. P. Féral \& B. David (Eds.), Echinoderm research (pp. 281-287). Lisse, The Netherlands: A.A. Balkema.

Matsuno, T., \& Tsushima, M. (2001). Carotenoids in sea urchins. In J. M. Lawrence (Ed.), Edible Sea urchins: Biology and ecology (pp. 115-138). Amsterdam, The Netherlands: Elsevier Science B.V.

McBride, S. C., Price, R. J., Tom, P. D., Lawrence, J. M., \& Lawrence, A. L. (2004). Comparison of gonad quality factors: Color, hardness and resilience, of Strongylocentrotus franciscanus between sea urchins fed prepared feed or algal diets and sea urchins harvested from the northern California fishery. Aquaculture, 233(1), 405-422.

McDermid, K. J., \& Stuercke, B. (2003). Nutritional composition of edible Hawaiian seaweeds. Journal of Applied Phycology, 15(6), 513-524.

Mercurio, S., \& Sugni, M. (2016). Comparing in vivo and in vitro approaches to study the hormonal regulation of sea urchin reproduction. Journal of the Marine Biological Association of the United Kingdom, 96(06), 1363-1372.

Miller, R. J., \& Mann, K. H. (1973). Ecological energetics of the seaweed zone in a marine bay on the Atlantic coast of Canada. III. Energy transformations by sea urchins. Marine Biology, 18(2), 99-114.

Minor, M. A., \& Scheibling, R. E. (1997). Effects of food ration and feeding regime on growth and reproduction of the sea urchin Strongylocentrotus droebachiensis. Marine Biology, 129(1), 159-167.

Neill, F. X., \& Pastor, R. (1973). Relaciones tróficas de Paracentrotus lividus (Lmk.) en la zona litoral. Investigación Pesquera, 37 (1), 1-7. 
Paredes, E., \& Bellas, J. (2014). Sea urchin (Paracentrotus lividus) cryopreserved embryos survival and growth: Effects of cryopreservation parameters and reproductive seasonality. CryoLetters, 35(6), 482-494.

Pearce, C. (2010). Sea-Urchin Aquaculture. Bulletin of the Aquaculture Association of Canada, 108-1, 1-2.

Pearce, C. M., Daggett, T. L., \& Robinson, S. M. C. (2002). Effect of protein source ratio and protein concentration in prepared diets on gonad yield and quality of the green sea urchin, Strongylocentrotus droebachiensis. Aquaculture, 214, 307-332.

Pearse, J. S., \& Cameron, R. A. (1991). Echinodermata: Echinoidea. In A. C. Giese, J. S. Pearse, \& V. B. Pearse (Eds.), Reproduction of marine invertebrates (Vol. VI, pp. 513-662). Pacific Grove: CA: The Boxwood Press.

Plank, L. R. (2000) The effect of dietary carotenoids on gonad growth, development and color in Lytechinus variegatus (Lamarck) (Echinodermata: Echinoidea) (Master's thesis). University of South Florida, Tampa, FL.

Plank, L. R., Lawrence, J. M., Lawrence, A. L., \& Olvera, R. M. (2002). The effect of dietary carotenoids on gonad production and carotenoid profiles in the sea urchin Lytechinus variegatus. Journal of the World Aquaculture Society, 33(2), $127-137$.

Repolho, T. F. B. R., Costa, M. H., Luís, O. J., \& Gago, J. A. E. M. (2011). Broodstock diet effect on sea urchin Paracentrotus lividus (Lamarck, 1816) endotrophic larvae development: Potential for their year-round use in environmental toxicology assessment. Ecotoxicology and Environmental Safety, 74(4), 584-592.

Robinson, S. M. C., Castell, J. D., \& Kennedy, E. J. (2002). Developing suitable colour in the gonads of cultured green sea urchins (Strongylocentrotus droebachiensis). Aquaculture, 206(3), 289-303.

Robinson, S. M. C., Lawrence, J. M., Burridge, L., Haya, K., Castell, J., \& Lawrence, A. L. (2004). Effectiveness of different pigment sources in colouring the gonads of the green sea urchin (Strongylocentrotus droebachiensis). In J. M. Lawrence \& O. Guzmán (Eds.), Sea urchins: Fisheries and ecology (pp. 215-221). Lancaster, PA: DEStech.

Rowley, R. J. (1990). Newly settled sea urchins in a kelp bed and urchin barren ground: A comparison of growth and mortality. Marine Ecology Progress Series, 62, 229-240.

Russell, M. P. (1998). Resource allocation plasticity in sea urchins: Rapid, diet induced, phenotypic changes in the green sea urchin, Strongylocentrotus droebachiensis (Müller). Journal of Experimental Marine Biology and Ecology, 220(1), 1-14.

San Martin, G. A. (1995). Contribution à la gestion des stocks d'oursins: étude des populations et transplantations de Paracentrotus lividus à Marseille (France, Méditerranée) et production de Loxechinus albus à Chiloe (Chili, Pacifique). (Doctoral dissertation). Université d'Aix-Marseille II, Marseille, France.

Sánchez-España, A. I., Martínez-Pita, I., \& García, F. J. (2004). Gonadal growth and reproduction in the commercial sea urchin Paracentrotus lividus (Lamarck, 1816) (Echinodermata: Echinoidea) from southern Spain. Hydrobiologia, 519(1-3), 61-72.

Sartori, D. (2013). Echinoculture: Rearing of Paracentrotus lividus in recirculating aquaculture system. Experimentations of artificial diets for sexual maturation (Doctoral dissertation). University of Naples "Federico II", Napoli, Italy.

Sartori, D., \& Gaion, A. (2015). Can sea urchins benefit from an artificial diet? Physiological and histological assessment for echinoculture feasibility evaluation. Aquaculture Nutrition, 22(6), 1214-1221.

Sartori, D., Pellegrini, D., Macchia, S., \& Gaion, A. (2016). Can echinoculture be a feasible and effective activity? Analysis of fast reliable breeding conditions to promote gonadal growth and sexual maturation in Paracentrotus lividus. Aquaculture, 451, 39-46.

Sartori, D., Scuderi, A., Sansone, G., \& Gaion, A. (2015). Echinoculture: The rearing of Paracentrotus lividus in a recirculating aquaculture system-Experiments of artificial diets for the maintenance of sexual maturation. Aquaculture International, 23(1), 111-125.

Schiener, P., Black, K. D., Stanley, M. S., \& Green, D. H. (2015). The seasonal variation in the chemical composition of the kelp species Laminaria digitata, Laminaria hyperborea, Saccharina latissima and Alaria esculenta. Journal of Applied Phycology, 27(1), 363-373.

Schlosser, S. C., Lupatsch, I., Lawrence, J. M., Lawrence, A. L., \& Shpigel, M. (2005). Protein and energy digestibility and gonad development of the European sea urchin Paracentrotus lividus (Lamarck) fed algal and prepared diets during spring and fall. Aquaculture Research, 36, 972-982.

Schur, A. I., \& Tappert, C. C. (2017). Speed and accuracy improvements in visual pattern recognition tasks by employing human assistance. In I. L. Nunes (Ed.), Advances in human factors and system interactions (pp. 293-300). Cham, Switzerland: Springer International.

Senaratna, M., Evans, L. H., Southam, L., \& Tsvetnenko, E. (2005). Effect of different feed formulations on feed efficiency, gonad yield and gonad quality in the purple sea urchin Heliocidaris erythrogramma. Aquaculture Nutrition, 11(3), 199-207.

Seo, J. S., Burri, B. J., Quan, Z., \& Neidlinger, T. R. (2005). Extraction and chromatography of carotenoids from pumpkin. Journal of Chromatography A, 1073(1), 371-375.

Shpigel, M., McBride, S. C., Marciano, S., \& Lupatsch, I. (2004). The effect of photoperiod and temperature on the reproduction of European sea urchin Paracentrotus lividus. Aquaculture, 232(1), 343-355.

Shpigel, M., McBride, S. C., Marciano, S., Ron, S., \& Ben-Amotz, A. (2005). Improving gonad colour and somatic index in the European sea urchin Paracentrotus lividus. Aquaculture, 245(1), 101-109. 
Shpigel, M., Schlosser, S. C., Ben-Amotz, A., Lawrence, A. L., \& Lawrence, J. M. (2006). Effects of dietary carotenoid on the gut and the gonad of the sea urchin Paracentrotus lividus. Aquaculture, 261(4), 1269-1280.

Spirlet, C., Grosjean, P., \& Jangoux, M. (1998a). Reproductive cycle of the echinoid Paracentrotus lividus: Analysis by means of the maturity index. Invertebrate Reproduction \& Development, 34(1), 69-81.

Spirlet, C., Grosjean, P., \& Jangoux, M. (1998b). Optimizing food distribution in closed-circuit cultivation of edible sea urchins (Paracentrotus lividus: Echinoidea). Aquatic Living Resources, 11(4), 273-277.

Spirlet, C., Grosjean, P., \& Jangoux, M. (2000). Optimization of gonad growth by manipulation of temperature and photoperiod in cultivated sea urchins, Paracentrotus lividus (Lamarck) (Echinodermata). Aquaculture, 185(1), 85-99.

Spirlet, C., Grosjean, P., \& Jangoux, M. (2001). Cultivation of Paracentrotus lividus (Echinodermata: Echinoidea) on extruded feeds: Digestive efficiency, somatic and gonadal growth. Aquaculture Nutrition, 7(2), 91-100.

Stefánsson, G., Kristinsson, H., Ziemer, N., Hannon, C. \& James, P. 2017. Markets for sea Urchins: A review of global supply and markets. In Internal Matis report: Skýrsla Matís. Reykjavik, Iceland, pp. 1-45. ISSN: 1670-7192.

Suckling, C. C., Symonds, R. C., Kelly, M. S., \& Young, A. J. (2011). The effect of artificial diets on gonad colour and biomass in the edible sea urchin Psammechinus miliaris. Aquaculture, 318(3), 335-342.

Svensson, P. A., Pélabon, C., Blount, J. D., Surai, P. F., \& Amundsen, T. (2006). Does female nuptial coloration reflect egg carotenoids and clutch quality in the two-spotted goby (Gobiusculus flavescens, Gobiidae)? Functional Ecology, 20(4), 689-698.

Symonds, R. C., Kelly, M. S., Caris-Veyrat, C., \& Young, A. J. (2007). Carotenoids in the sea urchin Paracentrotus lividus: Occurrence of $9^{\prime}$-cis-echinenone as the dominant carotenoid in gonad colour determination. Comparative Biochemistry and Physiology Part B: Biochemistry and Molecular Biology, 148(4), 432-444.

Tomšić, S., Conides, A. J., \& Aničić, I. (2015). Growth and gonad changes in stony sea urchin, Paracentrotus lividus (Lamarck, 1816) fed artificially formulated feed and benthic macrophyte diet. Naše More, 62(2), 85-90.

Tsushima, M., Kawakami, T., \& Matsuno, T. (1993). Metabolism of carotenoids in sea-urchin Pseudocentrotus depressus. Comparative Biochemistry and Physiology Part B: Comparative Biochemistry, 106(3), 737-741.

Tsushima, M., \& Matsuno, T. (1990). Comparative biochemical studies of carotenoids in sea-urchins-I. Comparative Biochemistry and Physiology Part B: Comparative Biochemistry, 96(4), 801-810.

Turchini, G. M., Torstensen, B. E., \& Ng, W. K. (2009). Fish oil replacement in finfish nutrition. Reviews in Aquaculture, 1(1), 10-57.

Turon, X., Giribet, G., López, S., \& Palacín, C. (1995). Growth and population structure of Paracentrotus lividus (Echinodermata: Echinoidea) in two contrasting habitats. Marine Ecology Progress Series, 122, 193-204.

Unuma, T., \& Walker, C. W. (2009). Relationship between gametogenesis and food quality in sea urchin gonads. Paper presented at the Aquaculture Technologies for Invertebrates: Proceedings of the 36th US-Japan Aquaculture Panel Symposium. NOAA Technical Memorandum NMFS-F/SPO-99. pp. 45-54

Vadas, R. L. (1977). Preferential feeding: An optimization strategy in sea urchins. Ecological Monographs, 47, $337-371$.

Vergés, A., Alcoverro, T., \& Romero, J. (2011). Plant defences and the role of epibiosis in mediating within-plant feeding choices of seagrass consumers. Oecologia, 166(2), 381-390.

Vergés, A., Becerro, M. A., Alcoverro, T., \& Romero, J. (2007). Variation in multiple traits of vegetative and reproductive seagrass tissues influences plant-herbivore interactions. Oecologia, 151(4), 675-686.

Verlaque, M. (1987). Relations entre Paracentrotus lividus (Lmk.) et le phytobenthos de Méditerranée occidentale. In C. F. Boudouresque (Ed.), Colloque international sur Paracentrotus lividus et les oursins comestibles (pp. 5-36). Marseille, France: GIS Posidonie.

Vizzini, S., Miccichè, L., Vaccaro, A., \& Mazzola, A. (2015). Use of fresh vegetable discards as sea urchin diet: Effect on gonad index and quality. Aquaculture International, 23(1), 127-139.

Volpe, M. G., Malinconico, M., Varricchio, E., \& Paolucci, M. (2010). Polysaccharides as biopolymers for food shelf-life extension: Recent patents. Recent Patents on Food, Nutrition \& Agriculture, 2(2), 129-139.

Walker, C. W., Unuma, T., \& Lesser, M. P. (2007). Gametogenesis and reproduction of sea urchins. In J. M. Lawrence (Ed.), Edible Sea urchins: Biology and ecology (pp. 11-33). Amsterdam, The Netherlands: Elsevier Science B.V..

Wiggins, R. H., Davidson, H. C., Harnsberger, H. R., Lauman, J. R., \& Goede, P. A. (2001). Image file formats: Past, present, and Future 1. RadioGraphics, 21(3), 789-798.

Yam, K. L., \& Papadakis, S. E. (2004). A simple digital imaging method for measuring and analyzing color of food surfaces. Journal of Food Engineering, 61(1), 137-142.

How to cite this article: Santos PM, Ferreira SMF, Albano P, Raposo A, Costa JL, Pombo A. Can artificial diets be a feasible alternative for the gonadal growth and maturation of the sea urchin Paracentrotus lividus (Lamarck, 1816)? J World Aquacult Soc. 2019;1-25. https://doi.org/10.1111/jwas.12656 